\title{
Nutrient regime and upwelling in the northern Benguela since the middle Holocene in a global context - a multi-proxy approach
}

\author{
Sandra Meisel ${ }^{1}$, Kay-Christian Emeis ${ }^{2}$, Ulrich Struck $^{*}, 1$ and Iris Kristen ${ }^{3}$ \\ ${ }^{1}$ Museum für Naturkunde, Leibniz-Institut für Evolutions- und Biodiversitätsforschung an der Humboldt-Universität zu Berlin, 10115 Berlin, \\ Germany, e-mail: Ulrich.Struck@mfn-berlin.de \\ ${ }^{2}$ Institut für Biogeochemie und Meereschemie, Universität Hamburg, Bundesstr. 55, 20146 Hamburg, Germany \\ ${ }^{3}$ Walaboda 69B, 7063 Praden, Switzerland
}

Received 15 November 2010

Accepted 22 February 2011

Published 3 August 2011

\section{Key Words}

Agulhas Water alkenone temperatures Benguela Upwelling climate forcing NADW nitrogen isotopes oxygen isotopes

\begin{abstract}
The last 5500 years of climate change and environmental response in the northern Benguela Coastal Upwelling are reconstructed by means of three sediment cores from the inner shelf off central Namibia. The study is based on nutrient $\left(\delta^{15} \mathrm{~N}, \delta^{13} \mathrm{C}\right)$ and productivity proxies (accumulation rates of total organic carbon; $\mathrm{AR}_{\mathrm{TOC}}$ ). Reconstructed sea surface temperatures (alkenone-derived SST) and temperatures at subsurface depths ( $T_{\delta 180}$; based on tests of planktonic foraminifers) reflect the physical boundary conditions. The selection of proxy indicators proved a valuable basis for robust palaeo-climatic reconstructions, with the resolution ranging from multi-decadal (NAM1) over centennial (core 178) to millennial scale (core 226620). The northern Benguela experienced pronounced and rapid perturbation during the middle and late Holocene, and apparently, not all are purely local in character. In fact, numerous correlations with records from the adjacent South African subcontinent and the northern hemisphere testify to global climatic teleconnections. The Holocene Hypsithermal, for instance, is just as evident as the Little Ice Age (LIA) and the Roman Warm Period. The marked SSTrise associated with the latter is substantiated by other marine and terrestrial data from the South African realm. The LIA (at least its early stages) manifests itself in intensified winds and upwelling, which accords with increased rainfall receipts above the continental interior. It appears that climate signals are transferred both via the atmosphere and ocean. The combined analysis of SST and $T_{\delta 180}$ proved a useful tool in order to differentiate between both pathways. SSTs are primarily controlled by the intensity of atmospheric circulation features, reflecting changes of upwelling-favourable winds. $T_{\delta 180}$ records the temperature of the source water and often correlates with global ocean conveyor speed due to varying inputs of warm Agulhas Water. It seems as though conveyor slowdown or acceleration not only affected the temperature of the source water but also its nutrient content. This relationship between source water quality and conveyor speed is already known from glacial times.
\end{abstract}

\section{Introduction}

The Benguela Coastal Upwelling is one of the most productive ecosystems on Earth, holding a considerable amount of the world's living marine resources. After mining, the fisheries sector represents the second largest export earner in the Namibian economy (van $\mathrm{Zyl}$ 2010). Over the last decades, conditions have been rapidly deteriorating due to overfishing, habitat degrada- tion, excessive nutrient loading, pollution effects, etc. The imminent threat of greenhouse warming raises additional concern (Shannon \& O'Toole 2003; Cochrane et al. 2007). By means of climate models, it has already been tried to evaluate the potential impact of global climate change on the coastal upwelling. However, predictions have been inconclusive and remain to be tested against additional palaeo-records (Cohen \& Tyson 1995).

* Corresponding author 
We investigate the variability of the northern Benguela Upwelling since the middle Holocene and try to examine the impact of past climate fluctuations on the system. This is in order to assess its vulnerability to external climate forcing and to gain a better understanding of what the system may await in the future. In this regard, it is necessary to distinguish global and regional perturbations from those that are purely local in character.

Much effort has already been put in a better understanding of glacial-interglacial fluctuations in the Benguela system. Owing to several ODP-expeditions on the continental slope off southwest Africa, the Pleistocene evolution of upwelling is relatively well known, (e.g. Diester-Haas et al. 1988; Oberhänsli 1991; Summerhayes et al. 1995; Kirst et al. 1999; Berger \& Wefer 2002; Kim et al. 2002). In contrast, only few studies (e.g. Emeis et al. 2009) have so far availed themselves of the high-resolution shelf sediments. Terrestrial-based geoarchives from the adjacent subcontinent are also scarce, usually poorly resolved and dated (Heine 2005). As a consequence, the hitherto documented history of Holocene climate variability is still fragmentary.

Compared to glacial-interglacial cycles, the Holocene is considered relatively stable. Nonetheless, palaeo-climate records from the North Atlantic show that periods comparable to the Little Ice Age and the Medieval Warming are recurrent features of the last millennia (Kreutz et al. 1997; Bianchi \& McCave 1999).

The Benguela is a highly dynamic system on both temporal and spatial scales, and the question is whether global perturbations are pronounced and far-reaching enough to leave clear marks in the central Namibian shelf environment, that is, to outweigh the immanent heterogeneity of the system.

Our investigation is based on three sediment cores from the central Namibian inner shelf. Their N-S alignment allows us to explore shifts of upwelling through time and to study local inhomogeneities. Palaeo-temperature estimates (alkenone unsaturation index UK'37 and $\delta^{18} \mathrm{O}$ from foraminiferal calite) hold clues to the intensity of upwelling and varying types of source waters. Isotopic abundance ratios of nitrogen $\left(\delta^{15} \mathrm{~N}\right)$ and organic carbon $\left(\delta^{13} \mathrm{C}_{\text {org }}\right)$, accumulation rates (AR) and total organic carbon (TOC) are used to reconstruct the nutrient regime and biological response at the time of deposition.

\section{Setting}

The Benguela Current represents the eastern boundary current of the South Atlantic anticyclonic gyre. A coastal upwelling system is situated at its eastern periphery. Coastal upwelling extends seaward about 150 to $200 \mathrm{~km}$, but upwelling filaments have been observed as far offshore as $1000 \mathrm{~km}$ (Shannon 1985; Lutjeharms \& Stockton 1987). Upwelling generally concentrates on seven cells located along the southwest African coast (Shannon \& Nelson 1996). The principal centre is in the vicinity of Lüderitz $\left(27^{\circ} \mathrm{S}\right)$ where strong upwelling occurs throughout the year. The Lüderitz Upwelling represents an environmental boundary between the northern and southern Benguela, creating two quasi-independent subsystems (Shannon \& Nelson 1996; Shannon \& O'Toole 2003; Mohrholz et al. 2008). Figure 1 provides an insight in the main oceanographic features and modern flow pattern.

The trade wind-driven upwelling taps water from up to $200 \mathrm{~m}$ depths (Mohrholz et al. 2008). The upwelled water represents a mélange of two upper central water masses, namely nutrient-rich and oxygen-poor South Atlantic Central Water (SACW) and well-oxygenated and nutrient-poor Eastern SACW (ESACW) (Mohrholz et al. 2008).

SACW originates from the Brazil-Malvinas Confluence region of the Subtropical Convergence in the SWAtlantic and is transported within the subtropical gyre and the equatorial current system into the Angola Dome region. From there it is eventually advected along the shelf into the northern Benguela via the Angola Current, or, more precisely, via its southward continuation in the form of a poleward undercurrent penetrating through the Angola-Benguela Front. Its maximum southward reach is estimated at $27^{\circ} \mathrm{S}$ (Mohrholz et al. 2008). Owing to its low oxygen content, SACW is partly held responsible for the sub- to anoxic condition above the shelf (Chapman \& Shannon 1987; Shannon \& Nelson 1996).

The second water mass, ESACW, is formed in the Agulhas Retroflection area in the south. It is a mixture of SACW from the subtropical gyre and varying amounts of warm Indian Ocean Central (Agulhas) Water injected into the South Atlantic through the Agulhas Current (Gordon 1986; Mohrholz et al. 2008). The Agulhas Retroflection area and southern Cape Basin are referred to as the 'Cape Cauldron', a zone of turbulent inter-ocean exchange where Indian and South Atlantic waters are thoroughly stirred and mixed (Boebel et al. 2003). The enhanced introduction of warm Agulhas Water is a recurrent event on (inter-) annual scales. On such occasions the Agulhas Water takes a more northerly path than usual, impacting on subsurface currents along the edge of the continental shelf (Shannon \& O'Toole 2003). On larger time scales, the amount of Indian Ocean Water injected into the South Atlantic is conjectured to depend on the intensity of the global thermohaline overturn (Gordon 1986). We will expatiate on this phenomenon below, when placing the northern Benguela in the context of global climate variability.

ESACW is carried northward along the upper continental slope and edge of the shelf by the Benguela Current itself (Gordon 1986; Mohrholz et al. 2008). The mixing of the northward flowing ESACW and southward flowing SACW occurs in the large transition area between the Angola-Benguela Front and the Lüderitz Upwelling. There is a clear seasonal variability in the proportion of well-oxygenated ESACW and oxygen-poor SACW on the shelf off Walvis Bay; this results in sea- 


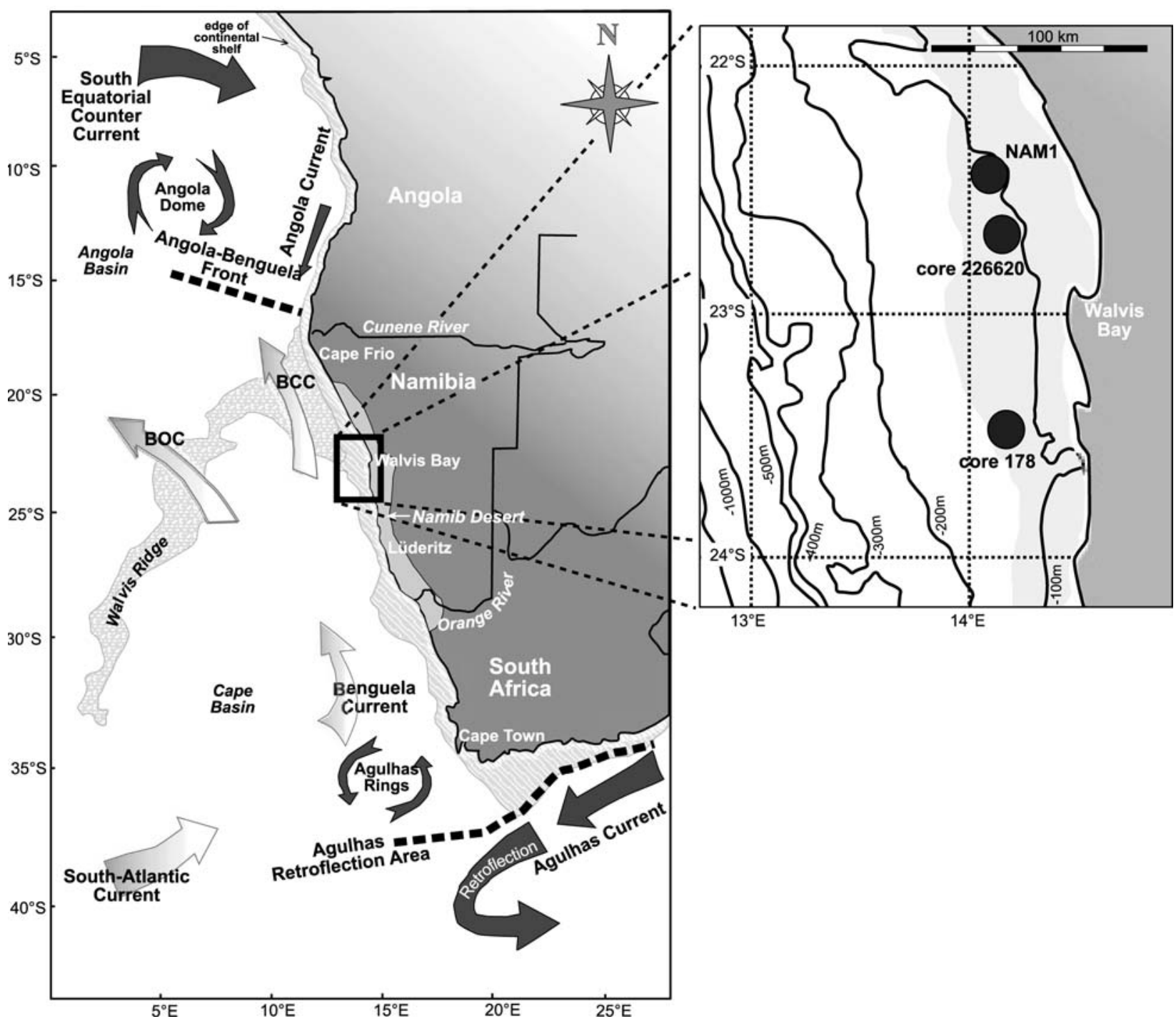

Figure 1. Oceanographic setting and area of investigation. The Benguela Coastal Upwelling extends from southern Angola along the west coast of Namibia and South Africa. At its northern and southern ends, the system is bordered by highly dynamic warm water regimes, the Angola-Benguela Front and the Agulhas Retroflection area respectively. The warm and nutrient-poor South Equatorial Counter Current (SECC) flows south-eastward towards the Angola Basin at subsurface depths until it reaches the surface at around $10^{\circ} \mathrm{S}$ where it continues southward as the Angola Current (Moroshkin et al. 1970). The equatorward flowing Benguela Current splits into the Benguela Oceanic Current (BOC) and the Benguela Coastal Current (BCC) at about $28^{\circ} \mathrm{S}$ (Stramma \& Peterson 1989). The BOC flows towards the northwest and is separated from the eastward flowing SECC by a large cyclonic gyre, the Angola Dome. BCC continues its coastal-parallel journey until meeting the Angola Current at the AngolaBenguela Front situated between 14 and $17^{\circ} \mathrm{S}$, depending on the season. Cold surface currents are lightly coloured, darker arrows denote warm surface currents (map modified after Holmes et al. 1999). The small chart zooms in on the area under investigation showing the locations of the three cores investigated herein. The diatomaceous muds are shaded grey.

sonally alternating oxygenation of the bottom waters. The interaction of the alongshore and Ekman-induced cross-shelf current components makes the flow regime extremely complex (Mohrholz et al. 2008). For detailed insight in today's nutrient dynamics and oceanographic features of the central Namibian shelf see Mohrholz et al. (2008) and Meisel et al. (2011).

Comprehensive reviews of the physical processes, chemistry and biology of the area are given by Chapman \& Shannon (1985), Shannon (1985), Shannon \& Pillar (1986), Shannon \& O'Toole (2003) and Shannon \& Nelson (1996).

\section{Material and methods}

\section{Sediment cores}

We investigated two gravity cores (178 and 226620) and one giantkastencore (NAM1) lying on a N-S-oriented transect off central Namibia. Some data have already been published previously (see clear listing in Table 1), however, in combination with hitherto unpublished data it is certainly worth showing it again.

General core properties are summarised in Table 1. The cores originate from the coastal parallel belt of organic-rich, diatomaceous ooze coating the inner shelf up to more or less $150 \mathrm{~m}$ water depth (Fig. 1). The thickness of the mud depends on the morphology of the basement transgressed in the course of the early Holocene (Bremner \& 
Table 1. General core characteristics (a), details about sample preparation and listing of parameters (b). Source studies of previously published data are mentioned. For information about pre-analysis sample preparation methods see Meisel \& Struck (2011). ${ }^{*} \delta^{15} \mathrm{~N}$-data from untreated sample splits have already been published by Emeis et al. (2009).

\begin{tabular}{|c|c|c|c|}
\hline a) general characteristics & NAM1 & 178 & 226620 \\
\hline cruise & Petr-Kottsov (04/04/1997) & Meteor Cruise M57-3 (18/03/2003) & Meteor Cruise M48-2 (05/08/2000) \\
\hline latitude/longitude (dez) & $22.67^{\circ} \mathrm{S} / 14.02^{\circ} \mathrm{E}$ & $23.76^{\circ} \mathrm{S} / 14.27^{\circ} \mathrm{E}$ & $22.75^{\circ} \mathrm{S} / 14.31^{\circ} \mathrm{E}$ \\
\hline water depth & $125 \mathrm{~m}$ & $114 \mathrm{~m}$ & $81 \mathrm{~m}$ \\
\hline core length & $545 \mathrm{~cm}$ & $561 \mathrm{~cm}$ & $380 \mathrm{~cm}$ \\
\hline age & 62 to $3036 \mathrm{BP}$ & 1757 to $3585 \mathrm{BP}$ & 860 to $5610 \mathrm{BP}$ \\
\hline b) core preparation and proxies & NAM 1 & 178 & 226620 \\
\hline syringe samples & at $1 \mathrm{~cm}$-intervals ( $\varnothing 5.5 \mathrm{a}$ ) & at $5 \mathrm{~cm}$-intervals ( $\varnothing 16.5 \mathrm{a}$ ) & at $5 \mathrm{~cm}$-intervals ( $\varnothing 62.5 \mathrm{a}$ ) \\
\hline TOC (wt\%) & $\begin{array}{l}\text { in-situ acidified sediment } \\
\text { Struck et al. (2002) }\end{array}$ & in-situ acidified sediment & in-situ acidified sediment \\
\hline$\delta^{13} \mathrm{C}_{\text {org }}(\% \circ)$ & $\begin{array}{l}\text { in-situ acidified sediment } \\
\text { Struck et al. (2002) }\end{array}$ & acidified plus rinsed sediment & acidified plus rinsed sediment \\
\hline$\delta^{15} \mathrm{~N}(\%)$ & $\begin{array}{l}\text { in-situ acidified sediment } \\
\text { Struck et al. (2002) }\end{array}$ & acidified plus rinsed sediment & acidified plus rinsed sediment* \\
\hline $\mathrm{SST}\left({ }^{\circ} \mathrm{C}\right)$ & UK'37 & UK'37 & $\begin{array}{l}\text { UK'37 } \\
\text { Emeis et al. (2009) }\end{array}$ \\
\hline sediment slices & $\begin{array}{l}\text { upper } 50 \mathrm{~cm}(\sim 330 \mathrm{BP}) \\
\text { cut in } 5 \mathrm{~cm} \text { thick slices; } \\
\text { then } 1 \mathrm{~cm} \text {-slices }\end{array}$ & $5 \mathrm{~cm}$ thick slices & $\begin{array}{l}2 \mathrm{~cm} \text { thick slices were taken at } \\
4 \mathrm{~cm} \text {-intervals }\end{array}$ \\
\hline$T_{\delta 180}\left({ }^{\circ} \mathrm{C}\right)$ & foraminiferal calcite & foraminiferal calcite & foraminiferal calcite \\
\hline
\end{tabular}

Willis 1993; Vogt 2002; Emeis et al. 2004). From today's perspective, core 178 is situated in the centre of the Central Namibian Upwelling Cell (extending from 22.7 and $24.5^{\circ} \mathrm{S}$; Shannon \& Nelson 1996) while NAM1 and core 226620 are situated below its northern fringes. In the shallow coastal waters primary production is particularly high (Meisel et al. 2011). High biogenic particle flux induces great oxygen demand in subsurface depths and contributes to the oxygen deficiency in bottom waters and sediments (Copenhagen 1953; Bakun \& Weeks 2004; Brüchert et al. 2004; Emeis et al. 2004). The lack of oxygen prevents bioturbation, often resulting in a continuously laminated sediment sequence.

Sample processing

Syringe samples were taken at $1 \mathrm{~cm}$-intervals from NAM1 (corresponding to an average sampling resolution of 5.5 a) and $5 \mathrm{~cm}$-intervals from core 178 (16.5 a) and 226620 (62.5 a) (Table 1). The sediment was desiccated, homogenised by grinding and split for isotope and alkenone measurements. After that, the cores were cut into slices, out of which the foraminiferal tests (Orbulina universa d'Orbigny, $1839)$ were picked. The carbonate shells are used for $\delta^{18} \mathrm{O}$-temperature reconstructions and ${ }^{14} \mathrm{C}$-dating. Table 1 provides details about the pre-analysis processing and a compilation of the parameters.

\section{Isotopic measurements}

\section{Sediments}

As to core 178 and $226620, \delta^{13} \mathrm{C}_{\text {org }}$ and $\delta^{15} \mathrm{~N}$ were determined on acidified plus rinsed material. With NAM1 the isotopic measurements are based on in-situ acidified sediment instead (published in Struck et al. 2002). The same applies to the analysis of TOC. Details about pre-analysis sample preparation (such as acidification plus rinsing and in-situ acidification) and implications for $\delta^{15} \mathrm{~N}$ are given in Meisel \& Struck (2011). Isotope abundance ratios are reported in the conventional $\delta$-notation in per mil (\%o) with respect to atmospheric $\mathrm{N}_{2}$ (AIR; concerning $\delta^{15} \mathrm{~N}$ ) and the VPDB-standard (concerning $\delta^{13} \mathrm{C}_{\text {org }}$ ). Analytical precision was $\pm 0.2 \%$, respectively ( $1 \sigma$ standard deviation). The reproducibility of [TOC] (in $w t \%$ ) is $\pm 3 \%$ of the real amount present.

\section{Foraminiferal calcite}

The samples contained between 5 and 30 tests of the planktonic, symbiont-bearing foraminifer $O$. universa. Prior to analysis, the tests were soaked in methyl alcohol and cleansed of contaminants in an ultrasonic bath. Excess alcohol was removed with a pipette. The volatile residual was allowed to evaporate in the heating oven at $40^{\circ} \mathrm{C}$. During measurement, the carbonate dissolves in orthophosphoric acid at constant $72{ }^{\circ} \mathrm{C}$. The $\delta^{18} \mathrm{O}$-values in the calcite $\left(\delta^{18} \mathrm{O}_{\text {calcite }}\right)$ are related to the VPDB-standard (reported in \%o). Reproducibility of replicates was generally below $\pm 0.1 \%$, which corresponds to $\pm 0.5^{\circ} \mathrm{C}$.

Carbon isotopes in foraminiferal calcite are much more susceptible to disequilibrium effects than oxygen isotopes. So-called "vital effects", processes such as foraminiferal metabolism and photosynthetic activity of symbionts are capable of changing the isotopic composition of the $\mathrm{CO}_{2}$ available for calcification (Spero \& Deniro 1987; Wefer \& Berger 1991; Mulitza et al. 1999). We decided therefore to do without the $\delta^{13} C_{\text {calcite-signals as they provide rather unclear insights }}$ in the nutrient regime, only.

\section{Temperature reconstruction}

Subsurface depths $\left(\delta^{18} O_{\text {calcite }}\right)$

The $\delta^{18} \mathrm{O}_{\text {calcite-signals are a function of the temperature and oxygen }}$ isotope composition of the water $\left(\delta_{\mathrm{w}}\right)$ during shell accretion (Niebler et al. 1999). According to the global ocean isotope curve of Fairbanks (1989), variations in $\delta_{\mathrm{w}}$ are negligible for the period of investigation. During the last 5000 years the decline in $\delta_{\mathrm{w}}$ due to meltwater discharge was actually lower than the precision of the method. This is why isotopic fluctuations are interpreted solely in terms of fluctuating water temperature. Disequilibrium effects (offset between the $\delta^{18} \mathrm{O}_{\text {calcite-value }}$ 
and the isotopic signature of calcite formed in thermodynamic equilibrium) are likewise negligible (Niebler et al. 1999). The palaeo-temperature equation applied describes low-light conditions where symbiont activity is moderate (Bemis et al. 1998).

$T_{\delta 180}\left({ }^{\circ} \mathrm{C}\right)=16.5-4.8 \times\left(\delta_{\mathrm{c}}-\delta_{\mathrm{w}}\right) \quad$ with $\quad \delta=-0.22$

( $\delta_{\mathrm{w}}$ is corrected by $-0.22 \%$ in order to adjust the oxygen isotope values in $\mathrm{H}_{2} \mathrm{O}$ (measured in VSMOW) to the VPDB-scale (Erez \& Luz 1983)).

O. universa is a tropical to subpolar species. Generally, planktonic foraminifera do rarely have a preferred depth habitat but adapt to the respective hydrological conditions (Ravelo \& Fairbanks 1992; Hemleben \& Bijma 1994; Tedesco et al. 2007)

To our knowledge there are yet no details about $O$. universa population dynamics in the Benguela Upwelling. Despite its algal symbionts, it is not necessarily bound to the photic zone. By and large, O. universa is considered an intermediate dweller. Its depth habitat extends from subthermocline depth into the mixed layer, varying with season, ontogeny, lunar cyclicity, availability of nutrients, etc. (Murray 1991; Hemleben \& Bijma 1994; Tedesco et al. 2007). These changes in calcification depth are considered the reason for the typical fuzziness of the $T_{\delta 180}$-signal.

Note that a sediment assemblage represents an integration of species growing at different seasons and depths. We anticipate that the range of $\delta^{18} \mathrm{O}_{\text {calcite-signals of the assemblage approximates the total }}$ temperature range through the depth habitat. Tedesco et al. (2007)

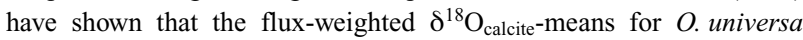
are close to their respective unweighted annual $\delta^{18} \mathrm{O}_{\text {calcite-means, indi- }}$

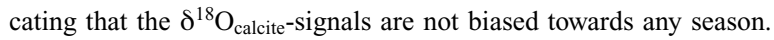

\section{Sea surface temperature (SST)}

Sea surface temperatures (SST) are determined by means of alkenone UK'37-records in phytoplankton dwelling in the uppermost surface layers up to $2 \mathrm{~m}$ water depth. The analytical error estimated for the method is $<0.4{ }^{\circ} \mathrm{C}$ in repeated determinations of individual samples (Emeis et al. 2009). The method is described in detail by Blanz et al. (2005).

Photosynthetic activity (i.e. alkenone production) is controlled by insolation and nutrient supply. Both are not constant throughout the year. Equatorward of the two tropics, insolation reaches its maximum twice a year (Lorenz et al. 2006). Upwelling (and thus nutrient supply) is most intense from winter to early spring (September to November) in the northern Benguela (Hart \& Currie 1960; Stander 1964; Nelson \& Hutchings 1983; Shannon 1985; Lutjeharms \& Meeuwis 1987). Despite the seasonality of insolation and nutrient supply, sediment trap studies above Walvis Ridge have shown that alkenone records approximate the mean annual temperature signal (Kirst et al. 1999 and references therein) (NB: This is different from high latitudes where alkenone-derived SSTs clearly reflect summer temperatures (Lorenz et al. 2006)). Holocene orbital forcing and associated changes in the seasonal cycle of solar irradiance (Lorenz et al. 2006) are not expected, therefore, to create a seasonal fingerprint in the alkenone data.

\section{Age determination}

Age determinations were made on calcite from snails, shells and foraminiferal tests $(O$. univers $a$ ), fish bone material or acid residual (Table 2; Fig. 2). The conversion of conventional radiocarbon ages $\left({ }^{14} \mathrm{C}\right.$-ages) into calendar years (BP; before present) was done by means of the calibration program CALIB 5.0 by Stuiver et al. (2005). Marine ${ }^{14} \mathrm{C}$-ages generally appear several hundred years older than their terrestrial counterparts. The Marine04 curve accommodates this age difference and includes a mean global ocean reservoir correction of 400 years. Usually, however, the correction varies slightly with location. $\Delta R$ takes account of the region-specific offset from the global

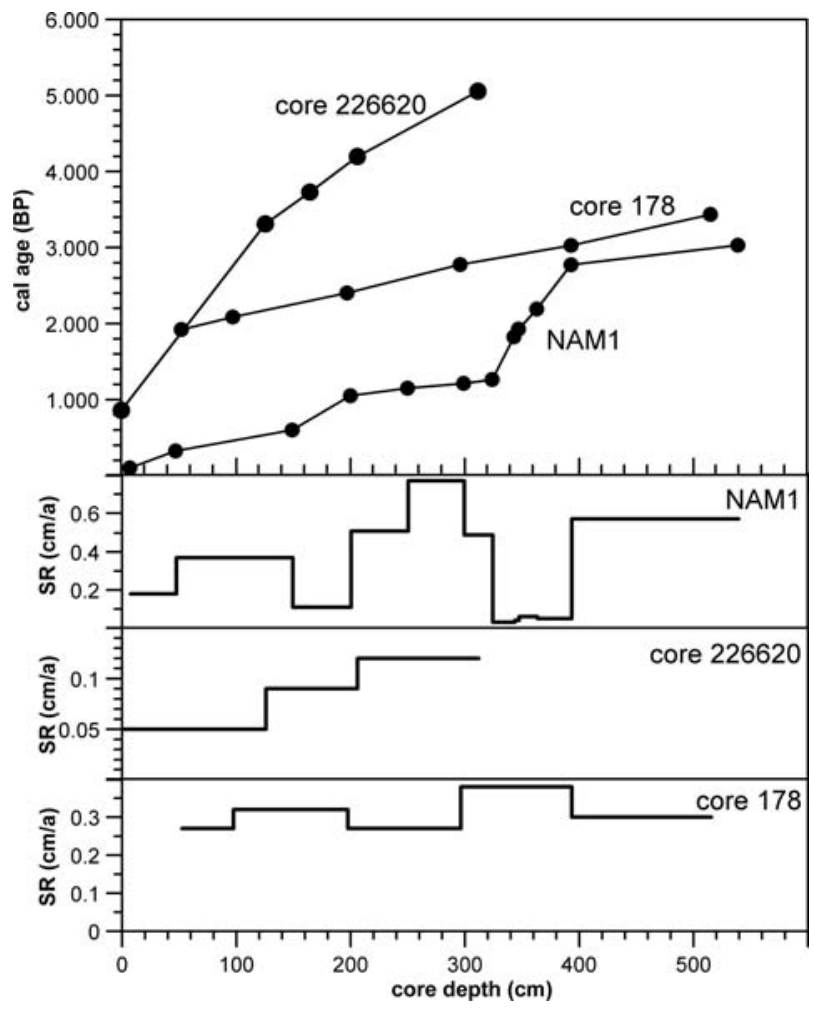

Figure 2. Core depth vs. calendar years. The age model is based on linear extrapolation through the age control points (based on BP-dates shown in Table 2). Corresponding sedimentation rates (SRs) are shown below. Core 178 exhibits the most constant SRs. In core 226620 the SRs and, as a consequence, the temporal resolution, are lowest. At the same time, however, it covers the largest time span. Note that NAM1 and core 178 are exclusively post-transgressive.

reservoir correction (Stuiver \& Braziunas 1993; Stuiver et al. 2005). To our knowledge, no $\Delta R$-values for the Benguela Upwelling have yet been published, hence the lacking consideration of a potential offset in our calculations $(\Delta R=0)$.

Since upwelling typically introduces "old", viz. ${ }^{14} \mathrm{C}$-deficient waters to the surface ocean, the ages might be slightly overestimated (Kim et al. 2002). As the core top of NAM1 was dated by means of the ${ }^{210} \mathrm{~Pb}$-method, we were able to evaluate the potential bias. This is because the risk of overestimation is eliminated with ${ }^{210} \mathrm{~Pb}$-dating (Christiansen \& Kunzendorf 1998). Given the reasonable age difference between the upper two age control points, the overestimation is considered negligible.

Note that most age determinations of core 226620 and NAM1 have already previously been published (Struck et al. 2002; Kristen 2003; Emeis et al. 2009). However, as uniform programme settings highly improve the temporal comparability of the cores, we decided to do our own conversion of ${ }^{14} \mathrm{C}$-ages into calendar years (Table 2). This is why the calendar years shown here deviate slightly from the ones already published.

\section{Results and discussion}

\section{Applicability of the proxy records}

Before going into the interpretation we look at the applicability of the proxies in use (see Table 3), paying particular attention to the characteristics and features that are specific to the coastal upwelling environment. 
Table 2. Age conversion via CALIB 5.0 (Stuiver et al. 2005), applying the calibration dataset Marine04. Programme settings: $\Delta R=0$; lab error $=1$; age span $=0$; lab error treated as multiplier. All BP-ages refer to AD $1950 .{ }^{14} \mathrm{C}$-ages of acid residual $($ see $*$ ) required a correction of +152 years prior to their transformation into calendar years (Kristen 2003). The core top of 226620 (core depth $=0 \mathrm{~cm}$ ) was dated by means of the associated MUC (Emeis et al. 2009). The uppermost age determination of NAM1 (core depth $=7.5 \mathrm{~cm}$ ) is based on Pb-dating and derives from the associated MUC 226870 (Kristen 2003). Accelerated mass spectrometry (AMS) ${ }^{14} \mathrm{C}$-dating was done at the Leibniz dating facility, Kiel, FRG. Pb-dating was conducted by the Gamma Dating Centre, Copenhagen by Dr. H. Kunzendorf.

\begin{tabular}{|c|c|c|c|c|}
\hline & core depth $(\mathrm{cm})$ & material used for age determination & ${ }^{14} \mathrm{C}$-ages (BP) & cal age (BP) \\
\hline \multirow[t]{12}{*}{ NAM1 } & 7.5 & Pb-dating & - & 101 \\
\hline & 47.5 & collagen (fish bone) & $680 \pm 25$ & 325 \\
\hline & 149.5 & collagen (fish bone) & $1025 \pm 30$ & 600 \\
\hline & 200.5 & acid remains & $1502 \pm 30^{*}$ & 1051 \\
\hline & 250.5 & acid remains & $1587 \pm 40^{*}$ & 1150 \\
\hline & 299.5 & acid remains & $1647 \pm 30^{*}$ & 1213 \\
\hline & 324.5 & carbonate (snail, shells) & $1705 \pm 25$ & 1264 \\
\hline & 343.0 & acid remains & $2222 \pm 35^{*}$ & 1824 \\
\hline & 347.5 & collagen (fish bone) & $2315 \pm 25$ & 1927 \\
\hline & 363.5 & carbonate (snail, shells) & $2515 \pm 25$ & 2191 \\
\hline & 393.5 & carbonate (snail, shells) & $3005 \pm 30$ & 2773 \\
\hline & 539.5 & acid remains & $3217 \pm 45^{*}$ & 3031 \\
\hline \multirow[t]{6}{*}{ core 178} & 52.5 & O. universa & $2310 \pm 30$ & 1922 \\
\hline & 97.5 & O. universa & $2445 \pm 30$ & 2086 \\
\hline & 197.5 & O. universa & $2710 \pm 30$ & 2403 \\
\hline & 296.5 & O. universa & $3005+40$ & 2776 \\
\hline & 393.5 & O. universa & $3215 \pm 35$ & 3028 \\
\hline & 515.5 & O. universa & $3550 \pm 35$ & 3435 \\
\hline \multirow[t]{5}{*}{ core 226620} & 0 & O. universa & $1315 \pm 25$ & 860 \\
\hline & 126.0 & O. universa & $3430 \pm 30$ & 3311 \\
\hline & 165.0 & O. universa & $3785 \pm 25$ & 3729 \\
\hline & 206.5 & O. universa & $4135 \pm 25$ & 4197 \\
\hline & 312.0 & O. universa & $4785 \pm 35$ & 5056 \\
\hline
\end{tabular}

Temperature records (SST, $\left.T_{\delta 180}, \Delta T\right)$

From today's perspective, core 178 lies in the centre of upwelling where modern SSTs are lowest. NAM1 and core 226620 are situated below the northern fringes of the cell where modern SSTs are slightly higher. For the time frame overlapping (3036 to $1757 \mathrm{BP}$; Table 1) median SST recorded by the cores agree with today's conditions concerning both the $\mathrm{N}-\mathrm{S}$-gradient and absolute values (NAM1: $16.0^{\circ} \mathrm{C}$; core $226620: 15.1{ }^{\circ} \mathrm{C}$; core 178: $15.0^{\circ} \mathrm{C}$ ) (see Meisel et al. 2011).

CTD-measurements on the central Namibian inner shelf have shown that water column stratification is poor. The seasonal thermocline situated between 10 and $20 \mathrm{~m}$ depth is weak and even though measurements were taken off the main upwelling season, the tempera-

Table 3. A listing of the proxy indicators used and their application.

\begin{tabular}{lll}
\hline proxy indicators & & information and use \\
\hline $\mathrm{AR}_{\mathrm{TOC}}\left(\mathrm{mg} / \mathrm{cm}^{2} / \mathrm{a}\right)$ & accumulation rates of total organic carbon & primary production rates \\
$\delta^{13} \mathrm{C}_{\text {org }}(\%)$ & isotope ratios of organic carbon in the sediment & relative $\mathrm{CO}_{2}$-consumption \\
$\delta^{15} \mathrm{~N}(\%)$ & isotope ratios of sedimentary nitrogen & $\begin{array}{l}\text { denitrification (i.e. } \mathrm{O}_{2} \text { in source waters), relative } \\
\mathrm{NO}_{3}{ }^{-} \text {-consumption }\end{array}$ \\
$\mathrm{SST}\left({ }^{\circ} \mathrm{C}\right)$ & sea surface temperature $(\mathrm{UK}$ '37-based) & temperature of the source water \\
$T_{\delta 180}\left({ }^{\circ} \mathrm{C}\right)$ & temperature reconstructions based on oxygen isotope & \\
$\Delta T\left({ }^{\circ} \mathrm{C}\right)$ & ratios in calcite from planktic foraminifers & mixing of the upper water column
\end{tabular}


ture offsets between surface and bottom waters rarely exceed $2{ }^{\circ} \mathrm{C}$ (Meisel et al. 2011). Reconstructed temperature offsets much higher than that $\left(\Delta T\right.$ up to $8{ }^{\circ} \mathrm{C}$; Fig. $3 \mathrm{C}$ ), as recorded by the difference between SST and $T_{\delta 18 \mathrm{O}}$, suggest the semi-allochthonous nature of the foraminiferal tests. It is plausible to anticipate that the foraminifers are advected from the middle and outer shelf areas where subsurface temperatures between 10 and $12{ }^{\circ} \mathrm{C}$ (corresponding to the main temperature range $T_{\delta 18 \mathrm{O}}$ straddles in between) are common. The lateral transport of the species further adds to the fuzziness of the $T_{\delta 180}$-record. As $T_{\delta 180}$ may not be purely in-situ in nature, $\Delta T$ does not exactly monitor vertical but rather diagonal temperature gradients.

Leaving aside such biases, increasing or decreasing $T_{\delta 180 \text {-values are ascribed to deeper or shallower pene- }}$ tration of wind- and wave-induced mixing and a corresponding weakening or strengthening of the thermocline. Moreover, the interpretation of $T_{\delta 180}$ needs to take account of possible variations in the temperature of the source water. Obviously, variations in the temperature of the source water also imprint themselves on SST. As a consequence, SST-changes cannot be simply ascribed to variably intense upwelling of cold subsurface waters. As we will see, it is sometimes not easy to clearly differentiate between upwelling-related or source water-related SST-changes.

Although being valid with reservation only, $\Delta T$ gives an immediate idea of how well the upper water column is mixed. Declining $\Delta T$ based on rising $T_{\delta 180}$, suggests a deeper penetration of wind- and wave-induced mixing. By contrast, declining $\Delta T$ based on falling SST, rather suggests intensified upwelling. Slackened upwelling manifests itself in rising SSTs, instead. As the winds weaken, the water column stratifies and the surface layer responds more sensitively to insolation.

\section{Accumulation and sedimentation rates (AR, SR)}

Average [TOC] amounts to $4 \mathrm{wt} \%$ in core 226620 and $7 \mathrm{wt} \%$ in NAM1 and core 178 . This roughly corresponds to the mean organic carbon content typically found in sediments below coastal upwelling regions (Berger \& Wefer 2002). [TOC] tends to be diluted by varying amounts of other constituents like carbonate, siliceous matter, etc. By considering accumulation rates $\left(\mathrm{AR}_{\mathrm{TOC}}\right)$ such biases are circumvented.

Variations in $\mathrm{AR}_{\mathrm{TOC}}$ reflect changes in biological production and provide, therefore, indirect information about nutrient supply, upwelling and the local wind conditions. In core $178, \mathrm{AR}_{\mathrm{TOC}}$ appears to work particularly well as such proxy indicator: Elevated $\mathrm{AR}_{\mathrm{TOC}}$ generally comes along with intensified mixing ( $\Delta T$ low) and correspondingly sound nutrient supply (around 2900 and 2200 BP; Fig. 3C). In contrast, low $\mathrm{AR}_{\mathrm{TOC}}$ coincides with a short-term increase in $\Delta T$ (approx. $2600 \mathrm{BP}$ ).

Note, however, that sedimentary archives tend to exaggerate variations in organic matter $(\mathrm{OM})$ (Berger \&
Wefer 2002): High flux promotes the preservation of organic material due to rapid burial and the lack of oxygen (Libes \& Deuser 1988; Montoya 1994; Ostrom et al. 1997; Sachs \& Repeta 1999; Holmes et al. 2002). During periods of low flux, ventilation improves and a much smaller proportion of OM escapes degradation. NAM1 documents these mechanisms perfectly well: As shown by the simplified sketch in Figure 3A, high ARs are generally accompanied by a densely laminated sediment sequence. The apparent absence of bioturbating organisms suggests scarce amounts of bottom oxygen. By contrast, at low ARs laminae are usually rare or completely lacking.

Note that the rapid alternations of production rates are due to the fact that age determinations are preferentially conducted at the bottom and top of a laminated sequence.

The sedimentation rates of core 226620 are consistent with the mean SR of the diatomaceous muds, which is estimated at $1 \mathrm{~mm} / \mathrm{a}$ (Bremner \& Willis 1993). SR and AR in NAM1 and core 178 are manifold higher (Fig. 3). It seems as though NAM1 and core 178 originate from some natural sediment trap, i.e. a morphological depression such as a submarine canyon for instance, where sediments are protected against erosion and accumulation rates greatly enhanced for gravitational reasons. This circumstance poses no problem as our interpretation is not concerned about absolute values but relative fluctuations instead.

Above all this, however, the usefulness of ARs as a meaningful proxy strongly depends on regular age determinations. The longer the time interval between two age control points, the bigger the risk that fluctuations are obliterated and smoothed out. Unfortunately, this applies to the upper half of core 226620 (3311 to $860 \mathrm{BP}$ ) were age control points are scarce and ARs and SRs, by inference, poorly significant.

\section{Isotopic records $\left(\delta^{15} N, \delta^{13} C_{\text {org }}\right)$}

The combined study of $\delta^{15} \mathrm{~N}$ and $\delta^{13} \mathrm{C}_{\text {org }}$ is a valuable tool in the reconstruction of past nutrient regimes. The assimilation of $\mathrm{NO}_{3}{ }^{-}$and $\mathrm{CO}_{2}$ by phytoplankton is accompanied by isotope fractionation, with ${ }^{15} \mathrm{~N}$ and ${ }^{13} \mathrm{C}$ being preferentially left behind (only as long as nutrients are abundant though). The remaining nutrient pool becomes progressively "heavier" and with it the phytoplankton that grows within that pool (e.g. Wada \& Hattori 1978; Wada 1980; Montoya 1994; Ostrom et al. 1997; Waser et al. 1998).

Fluctuations in $\delta^{15} \mathrm{~N}$ and $\delta^{13} \mathrm{C}_{\text {org }}$ can be related to varying degrees of relative nutrient consumption ("relative" refers to the initial amount present) (e.g. Francois et al. 1992; Altabet \& Francois 1994; Montoya \& McCarthy 1995; Voss et al. 1996; Ostrom et al. 1997; Holmes et al. 2002). Relative consumption changes along with biological production and/or the nutrient supply. The nutrient supply, in turn, not only depends 

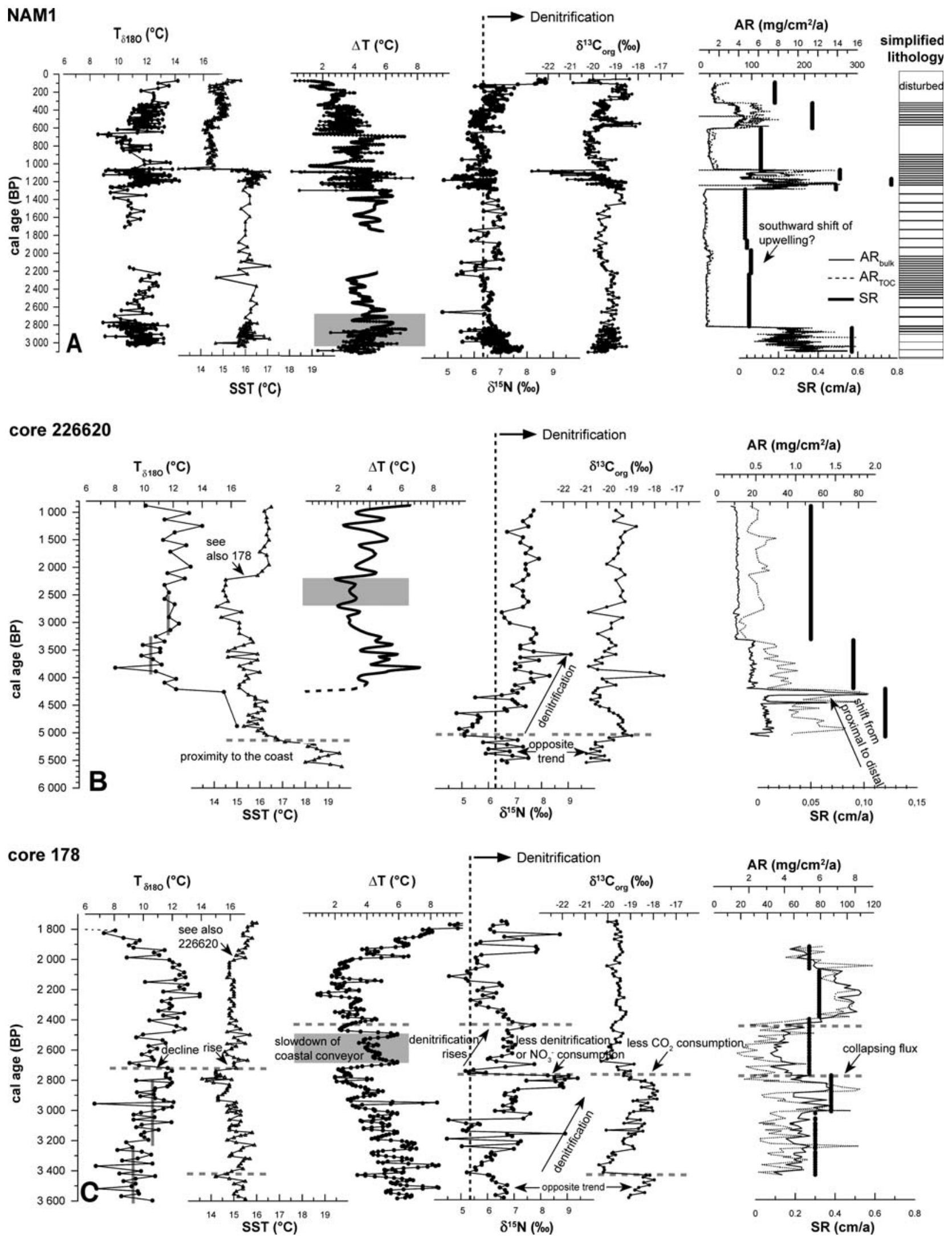

Figure 3. Proxy indicators vs. calendar years. From north to south: A. NAM1; B. Core 226620; C. Core 178. Data that are already published elsewhere are clearly listed in Table 1. Significant co-variations of the proxies are marked. Please note that it is only for SR, $\mathrm{AR}_{\text {bulk }}$ and $\mathrm{AR}_{\mathrm{TOC}}$ that the scales differ. The simplified lamination of NAM1 is based on an X-Ray (modified after Struck et al. 2002). No X-rays are available for core 178 and 226620. $\Delta T$-records are based on the offsets between SST and $T_{\delta 180}$. The interpolation of the SST- and $T_{\delta 180}$-data was computed by the akima method with 5 years-intervals. $\Delta T$-records older than $4100 \mathrm{BP}$ in (B) (dashed line) are regarded poorly significant because of lacking $T_{\delta 180}$-data compared to SST-records. The pronounced decline in $T_{\delta 180}$ (dashed line) at the top of core $178(\mathrm{C})$ should not be overinterpreted due to the possibly allochthonous nature of the $T_{\delta 180^{-}}$signals (see text). 
on the intensity of upwelling and mixing of the upper water column, but also depends on the type of source water.

The $\delta^{13} \mathrm{C}_{\text {org }}$-core signals reach up to $-18 \%$, dropping only rarely below $-21 \%$. According to Rau (1994), values that high are usually associated with SST above $25^{\circ} \mathrm{C}$ (NB: The higher the temperature, the less $\mathrm{CO}_{2}$ dissolves in the water, at the same time driving aqueous $\delta^{13} \mathrm{C}_{\mathrm{CO} 2}-$ and, as a consequence, $\delta^{13} \mathrm{C}_{\mathrm{org}}$ - signals towards higher values). The significant ${ }^{13} \mathrm{C}$ enrichment of the diatomaceous muds at surface ocean temperatures of $\pm 16^{\circ} \mathrm{C}$ results from high primary production and high relative consumption.

Average $\delta^{15} \mathrm{~N}$ of the source water nitrate $\left(\delta^{15} \mathrm{~N}_{\text {nitrate }}\right)$ is estimated at $5.5 \%$ (Sigman et al. 1997, 2000; Ren et al. 2009). Sedimentary $\delta^{15} \mathrm{~N}$-signals below that suggest a surplus in nitrate and comparably low relative consumption. Our cores, however, mostly exhibit higher values. Given the proximity to the nutrient source and upwelling, prior consumption can hardly be held responsible for the ${ }^{15} \mathrm{~N}$-enrichment. Instead, shifts beyond $5.5 \%$ are taken as an indication of denitrification in the source waters (see dashed line in Figure 3).

During denitrification, anaerobic prokaryotes use nitrate instead of oxygen in order to oxidise OM. Due to the preference of denitrifying bacteria for ${ }^{14} \mathrm{~N}-\mathrm{NO}_{3}{ }^{-}$, the $\mathrm{NO}_{3}{ }^{-}$-pool gets progressively enriched in ${ }^{15} \mathrm{~N}$ (Cline \& Kaplan 1975; Montoya 1994; Holmes et al. 1996). Denitrification sets in as soon as oxygen drops below $0.2 \mathrm{ml} / 1$ (Bubnov 1972; Knowles 1982; Packard et al. 1983). In the modern central Namibian shelf environment, bottom $\mathrm{O}_{2}$ is frequently below detection level and denitrification strongly influences the $\delta^{15} \mathrm{~N}$-signal of the primary product (Brüchert et al. 2004; Lavik et al. 2009; Meisel et al. 2011).

The oxygen deficiency itself results from a combination of several factors: The varying poleward advection of hypoxic SACW plays a major role in the oxygen dynamics of the shelf (Chapman \& Shannon 1987; Shannon \& Nelson 1996; Mohrholz et al. 2008). High primary production and vertical flux enhance the local oxygen consumption due to respiration and often contribute to deteriorated $\mathrm{O}_{2}$-supply in subsurface depths (Libes \& Deuser 1988; Tyrrell \& Lucas 2002; GayeHaake et al. 2005). Nowadays, the subsurface transport of oxygen-rich ESACW from the shelf edge onto the shelf seasonally balances the oxygen consumption below the surface mixed layer (Mohrholz et al. 2008). However, the more time it takes for the Ekman compensation current to travel up the shelf, the more organic matter decay it is supporting on its way and the greater the $\mathrm{O}_{2}$-consumption due to respiration. During periods of slackened upwelling, the cross-shelf conveyor system slows down and the Ekman-induced $\mathrm{O}_{2}$ replenishment is less effective.

Diagenesis often limits the use of $\delta^{15} \mathrm{~N}$ as a palaeoproxy. However, recent investigations have shown that pre-analysis acidification plus rinsing is capable of eliminating decomposition-derived influences in the diatomaceous muds (Meisel \& Struck 2011). As regards core 226620 and 178 , we therefore expect related $\delta^{15} \mathrm{~N}$-shifts to be erased. This does not apply to NAM1 where measurements are based on in-situ acidified sediment instead (published in Struck et al. 2002; Table 1). Although the lack of oxygen in the shallow coastal waters promotes the preservation of the original signal (Meisel et al. 2011), the potential influence of OM decomposition has to be kept in mind with the $\delta^{15} \mathrm{~N}$-signals in NAM1 (Meisel \& Struck 2011).

This restriction aside, $\delta^{15} \mathrm{~N}$-signals are predominantly to be interpreted in terms of relative nutrient consumption, denitrification or a combination of both. Declining $\delta^{15} \mathrm{~N}$-values, for instance, do not necessarily result from reduced relative consumption but could equally be due to less denitrification in the bottom waters travelling up the shelf (NB: Anammox (anaerobic ammonium oxidation by nitrate and/or nitrite to yield $\mathrm{N}_{2}$ ) is an additional process strongly interfering with the nitrogen cycle above the central Nambian shelf (Kuypers et al. 2005). As far as we know, however, no study has yet examined whether or not annamox is associated with nitrogen isotope fractionation. It cannot be ruled out that anammox also impinges on the nutrient's $\delta^{15} \mathrm{~N}$-signature).

This allochthonous influence on $\delta^{15} \mathrm{~N}_{\text {nitrate }}$ is why $\delta^{15} \mathrm{~N}$ sometimes not co-varies with $\delta^{13} \mathrm{C}_{\text {org }}$ or the other proxies. The $\delta^{13} \mathrm{C}_{\text {org }}$-records are easier to handle than $\delta^{15} \mathrm{~N}$ as they are mainly controlled by relative $\mathrm{CO}_{2}$-consumption; there is no such process that compares to denitrification.

Note that $\mathrm{OM}$ is primarily of marine origin. Neither is there a major river draining into the ocean nor can terrestrial material introduced by winds as dust exert enough influence to outweigh the excess of phytoplankton biomass and bias the isotopic signal (Holmes et al. 1998; Tyrrell \& Lucas 2002). Molar $\mathrm{C}_{\text {org }} / \mathrm{N}$ ratios of suspended particulate matter confirm the primarily marine nature of the material (Meisel et al. 2011).

Note that most trends and peaks discussed below significantly exceed the precision of the methods. Still, there are some fluctuations that deserve a mention notwithstanding being only subtle and smaller than the precision. This is when co-variations amongst the proxies substantiate the credibility and significance of the fluctuation.

\section{Climatic reconstructions}

This section relates exclusively to own data, describing and discussing co-variances between the proxy indicators and between the cores. The interpretation is rather "local-minded" and it is only in the following section that the core data are compared to other palaeo-archives and placed in a regional and global context.

With core 226620, our data set in around $5600 \mathrm{BP}$ (Fig. 3B). This is about 1000 years before the sea level rise has come to an end and the modern shelf circulation pattern is established (Emeis et al. 2009). The sedi- 
mentation is characterised by a sand-sized quartz minerals with various shell remains imbedded. This and concomitantly high SSTs $\left(>19^{\circ} \mathrm{C}\right)$ fit the proximity to the shore at that time.

The beginning sedimentation of silt and muds around $5200 \mathrm{BP}$ testifies to the flooding of the shelf and the resultant shift from proximal to distal depositional settings. The simultaneous drop in SST by almost $5^{\circ} \mathrm{C}$ suggests an increasing influence of cold, upwelled waters. At first, $\delta^{13} \mathrm{C}_{\text {org }}$ and $\delta^{15} \mathrm{~N}$ respond with a sudden rise and drop respectively (Fig. 3B). Their opposite development results from the different availability of $\mathrm{CO}_{2}$ and $\mathrm{NO}_{3}{ }^{-}$(Ostrom \& Macko 1991). Contrary to $\mathrm{CO}_{2}, \mathrm{NO}_{3}{ }^{-}$is often in limited supply. With the onset of upwelling, however, the photic zone experiences an instant and hitherto unknown abundance of nitrate. Relative consumption declines driving the system towards lower $\delta^{15} \mathrm{~N}$-signatures in the nitrate pool and primary product (Ostrom \& Macko 1991; Altabet \& Francois 1994; Holmes et al. 1996, 1999). As primary production flourishes, $\mathrm{CO}_{2}$-utilisation and $\delta^{13} \mathrm{C}_{\text {org }}$ rise in tandem (Hollander \& McKenzie 1991; Schelske \& Hodell 1991; Rau 1994; Fry 1996).

$5100 \mathrm{BP}$ the trends are being reversed (Fig. 3B, dotted line). The decline in $\delta^{13} \mathrm{C}_{\text {org }}$ (from approximately -19 to $-20.5 \%$ ) suggests increasing supply of $\mathrm{CO}_{2}$, as the coastal upwelling system is about to develop (note that SSTs continue falling). The growing $\delta^{15} \mathrm{~N}-$ offset between sediments and marine nitrate $(5.5 \%$ ) testifies to increasing $\mathrm{O}_{2}$-depletion and denitrification. Around $4000 \mathrm{BP}$ sedimentary $\delta^{15} \mathrm{~N}$ has attained $\pm 7.5 \%$, which approximates today's level at that site (Meisel et al. 2011). The concomitant decline in ARs and SRs should not be mistaken as slackened productivity. It rather reflects the shift and transition from littoral to subtidal facies characteristics as the site moves offshore.

From $3600 \mathrm{BP}$ on, core 226620 is complemented by core 178 (Fig. 3C). Its higher resolution provides insight in decadal-scale variability. Between 3600 and $3400 \mathrm{BP}$, core 178 records an opposite development of $\delta^{13} \mathrm{C}_{\text {org }}$ and $\delta^{15} \mathrm{~N}$ at contemporaneously declining SSTs. A comparable situation already occurred 5200 BP (core 226620; q.v.).

The sudden collapse of $\delta^{13} \mathrm{C}_{\text {org }}$ at $3400 \mathrm{BP}$ is accompanied by a slight increase in SST (Fig. 3C, dotted line) while $\delta^{15} \mathrm{~N}$ continuous its previously initiated decline. $\mathrm{CO}_{2}$-consumption seems to drop as a response to slackened upwelling and scarce nutrient supply. The lacking reaction of $\delta^{15} \mathrm{~N}$ is somewhat intriguing.

Despite their different temporal resolution, the temperature records of core 226620 and 178 bear marked resemblances. On close examination, it is found that $T_{\delta 180}$ performs a slight but simultaneous jump $\left( \pm 1{ }^{\circ} \mathrm{C}\right)$ at approx. $3200 \mathrm{BP}$ in both cores. Before and after, $T_{\delta 180}$ oscillates around constant values (indicated by the vertical lines in Figures $3 \mathrm{~B}$ and $3 \mathrm{C}$ ). In the meanwhile, SST decreases more or less gradually in both cores. By $2800 \mathrm{BP}, \Delta T$ has fallen to $2{ }^{\circ} \mathrm{C}$. According to core 178 , primary production seems to benefit from increased nutrient supplies (Fig. $3 \mathrm{C}$ ): $\mathrm{AR}_{\mathrm{TOC}}$ increases (note the concomitant peak in NAM1; Fig. 3A), rising $\delta^{13} \mathrm{C}_{\text {org-values }}$ testify to high $\mathrm{CO}_{2}$-consumption. Rising $\delta^{15} \mathrm{~N}$ hints at increasingly denitrified and oxygen-deficient bottom waters. The rising flux of organic detritus might contribute to the lack of oxygen at the site of deposition. Intense $\delta^{15} \mathrm{~N}$-fluctuations superimposed on the upward $\delta^{15} \mathrm{~N}$-trend suggest intermittently reduced $\mathrm{O}_{2}$-consumption in the source waters and may indicate varying fractions of hypoxic SACW and well-oxygenated ESACW. Variation in the composition of the source waters and associated alternating oxygenation stages is a seasonal phenomenon, which, however, may also act on larger time scales. Interestingly, the highestamplitude variability coincides with the shift towards warmer $T_{\delta 180}$ around $3200 \mathrm{BP}$.

The period around $2700 \mathrm{BP}$ (slight age discrepancies are ascribed to dating uncertainties) marks significant and area-wide perturbations. All three cores register rising $\Delta T$ (Fig. 3, grey bars). Considering the proxy indicators as a whole, core 178 (Fig. 3C) provides the most conclusive insight. The divergence of SST and $T_{\delta 180}$ (see dotted line) suggests increased water column stratification. Rising SSTs imply slackened upwelling and a more sensitive response to insolation while falling $T_{\delta 18 \mathrm{O}}$ suggest a shallower penetration of wind-induced mixing. A potential cause might be a shift of the cyclonic wind stress and upwelling. The adverse effect on the replenishment with nutrients manifests itself in collapsing growth rates (see also NAM1; Fig. 3A). Diminished $\mathrm{CO}_{2}$-consumption, as evidenced by concomitantly falling $\delta^{13} \mathrm{C}_{\text {org }}$-values, fits the decline in photosynthetic activity. $\delta^{15} \mathrm{~N}$ declines drastically (from \pm 9.5 to $5.0 \%$ ) and although less distinct, NAM1 (Fig. 3A) exhibits a comparable development. Lower $\delta^{15} \mathrm{~N}$-signals may indicate less denitrification (i.e. rising oxygen in the bottom waters as the biogenic flux decreases), reduced relative nitrate utilisation or a combination of both.

Stratified conditions and reduced primary production persist for a couple of centuries ( 2700 to $2500 \mathrm{BP})$. This fact notwithstanding, $\delta^{15} \mathrm{~N}$-values rise again almost immediately after their pronounced drop around 2700 BP (Fig. 3C), suggesting that denitrification again dominates the signal. ARs remain low (Fig. 3C), implying that the lack of oxygen is hardly due to enhanced in-situ respiration. Slackened upwelling - as proposed before - and a slowdown of the coastal conveyor system offer a likely explanation. The more time it takes for the bottom water to travel up the shelf, the greater the $\mathrm{O}_{2}$-consumption and the bigger the shift towards higher $\delta^{15} \mathrm{~N}_{\text {nitrate}}$-signals.

Around $2500 \mathrm{BP} \Delta T$ drops due to increasing $T_{\delta 180}$ (Fig. 3C). Note that the warming of the source waters does not imprint itself back on SST. SST remains constant, which makes only sense if upwelling intensifies at the same time. An intensification of upwelling might account for the concomitantly increasing primary production and declining $\delta^{15} \mathrm{~N}$-values (Fig. 3C, dotted lines). 
The faster the cross-shelf conveyor, the less the time for denitrification to take effect.

The decline in ARs after $2200 \mathrm{BP}$ in core 178 (Fig. 3C) is difficult to interpret. SST remains constant and neither $\delta^{13} \mathrm{C}_{\text {org }}$ nor $\delta^{15} \mathrm{~N}$ provides any evidence of deteriorated nutrient supply.

The reaction of NAM1 compares rather poorly with the distinct trends in core 178. The rise in ARs and SRs centred around $2200 \mathrm{BP}$ is almost negligible and the downward trend of $\delta^{15} \mathrm{~N}$ is noticeable but much less pronounced (Figs 3A, C). Like today, NAM1 seemingly lay outside the high-productivity area, thus receiving attenuated signals only. This is further substantiated by the higher SSTs $\left( \pm 16^{\circ} \mathrm{C}\right)$ compared to both other cores $\left( \pm 15^{\circ} \mathrm{C}\right)$ around that time.

$2200 \mathrm{BP}$ core 226620 experiences a pronounced warming (Fig. 3B) in the course of which SST attains values similar to those recorded by NAM1. A possible explanation might be that upwelling has shifted further south. Core 178 is also affected. Unfortunately, the extent of the warming at site 178 remains in the dark as the record ends around $1800 \mathrm{BP}$ already (Fig. 3C). The slightly latter onset compared to core 226620 might either be real (relating to the southward shift of upwelling) or result from interpolation uncertainties. Anyway, NAM1 and later also core 226620 seem to have been beyond the direct influence of upwelling for nearly two millennia. Throughout the second and third millennium, productivity was scarce with mean SR amounting to $0.5 \mathrm{~mm} / \mathrm{a}$ only (Figs $3 \mathrm{~A}-\mathrm{B}$ ); this is merely half of the average SR reported for the diatomaceous muds (Bremner \& Willis 1993). Actually, the scenario resembles modern conditions according to which NAM1 and core 226620 are situated slightly north of the principal centre of upwelling.

In core 178 the rise in SST from $2000 \mathrm{BP}$ on is accompanied by a sharp decline in subsurface temperatures. Within two centuries, $T_{\delta 180}$ drops from 12 to nearly $3{ }^{\circ} \mathrm{C}$ (Fig. 3C). No such trend is recorded by core 226620 and as regards NAM1 the samples covering 2150 to $1700 \mathrm{BP}$ are unfortunately lost. The other proxies hold no further clues to the nature of the event either. The possibility that the foraminiferal tests are advected from colder subsurface waters further offshore cannot be excluded.

The reconstruction of the last millennium is exclusively based on NAM1 (Fig. 4). Its high-resolution data set is certainly special, although often not easy to interpret. The biggest surprise was the parallel up and down of temperature and productivity. According to theory, temperature and productivity are inversely correlated as intensified (or slackened) upwelling usually brings about high (or low) nutrient supplies and low (or high) SSTs (e.g. Holmes et al. 1999). In fact, Quaternary-age sediment cores from the continental slope off Walvis Bay display a close negative correlation between $\mathrm{AR}_{\mathrm{TOC}}$ and SST (Summerhayes et al. 1995; Kirst et al. 1999).

On the shelf, different mechanisms seem to operate. Figure 4 zooms in on the last 1400 years and shows that the relationship between $\mathrm{AR}_{\mathrm{TOC}}$ and $\mathrm{SST}$ is precisely opposite. Still, the marked co-variations amongst both proxy indicators definitively substantiate the credibility of the data.

The markedly high ARs between 1250 and 1000 BP are presumably due in part to improved preservation; oxygen seems to be lacking at the site of deposition, as inferred from the dense laminae. The simultaneous trend towards lower $\delta^{15} \mathrm{~N}$-signatures indicates that primary production benefits from increased nutrient supply. Compared to $\delta^{13} \mathrm{C}_{\text {org }}$, however, the fluctuation is comparably small and should not be overinterpreted.

In fact, the $\delta^{13} \mathrm{C}_{\text {org }}$-record deserves particular attention as it is in conflict with our hitherto applied way of interpretation. Different from $\mathrm{NO}_{3}{ }^{-}, \mathrm{CO}_{2}$ is usually abundant which is why increasing photosynthetic rates and $\mathrm{CO}_{2}$-consumption are normally accompanied by rising $\delta^{13} \mathrm{C}_{\text {org }}$-signatures. The fact that $\delta^{13} \mathrm{C}_{\text {org }}$ drops to values as low as $-22 \%$ during times of enhanced biological production suggests an unusually high surplus of isotopically light $\mathrm{CO}_{2}$. What are the reasons for this exceptionally high $\mathrm{CO}_{2}$-supply? "Nutrient trapping" associated with continuous remineralisation reactions as the subsurface waters travel up the shelf, might partly account for this surplus (note that "nutrient trapping" does not necessarily hold to the same extent for nitrate as for dissolved inorganic carbon). Where denitrification inhibits the parallel "supercharge" with $\mathrm{NO}_{3}{ }^{-}$, the source waters exhibit continuously rising $\mathrm{CO}_{2} / \mathrm{NO}_{3}{ }^{-}$ratios (Tyrrell \& Lucas 2002).

The grey band in Figure 4 marks a significant change in the properties of the system. Within only one century, the surface ocean cools by $1.5^{\circ} \mathrm{C}$. On closer examination SST appears tied to the developing of $T_{\delta 180}$. The cooling is accompanied by collapsing ARs. As SST drops, $\delta^{13} \mathrm{C}_{\text {org }}$ at first continues its steep decline but then suddenly jumps by nearly $4 \%$ back to former levels. The leap of $\delta^{13} \mathrm{C}_{\text {org }}$ as ARs collapse is as unusual as the above outlined decline at rising ARs. Again it shows that our hitherto applied line of reasoning does not bear the circumstances.

The abruptness of events shows that the properties of the system are able to flip in an instant. On the basis of the available evidence it seems like temperature and nutrient content of the source water are liable to pronounced changes through time. Contemporaneously high temperature and ARs in combination with relatively low $\delta^{13} C_{\text {org }}$ ("relatively" because $\delta^{13} C_{\text {org }}$-signal are still comparably ${ }^{13} \mathrm{C}$-enriched) around $1200 \mathrm{BP}$ are best explained by the presence of "warm" and nutrientrich source waters (with "nutrient trapping" potentially contributing to the surplus in $\mathrm{CO}_{2}$ ). The subsequent collapse in AR and SST accompanied by the leap in $\delta^{13} C_{\text {org }}$ altogether suggests reduced influence of this warm and nutrient-rich water mass.

The presence of warm and nutrient-rich source water including its potential to imprint itself back on SST offers a reasonable explanation for the direct (instead of inverse) correlation between $\mathrm{SST}$ and $\mathrm{AR}_{\mathrm{TOC}}$. Further 


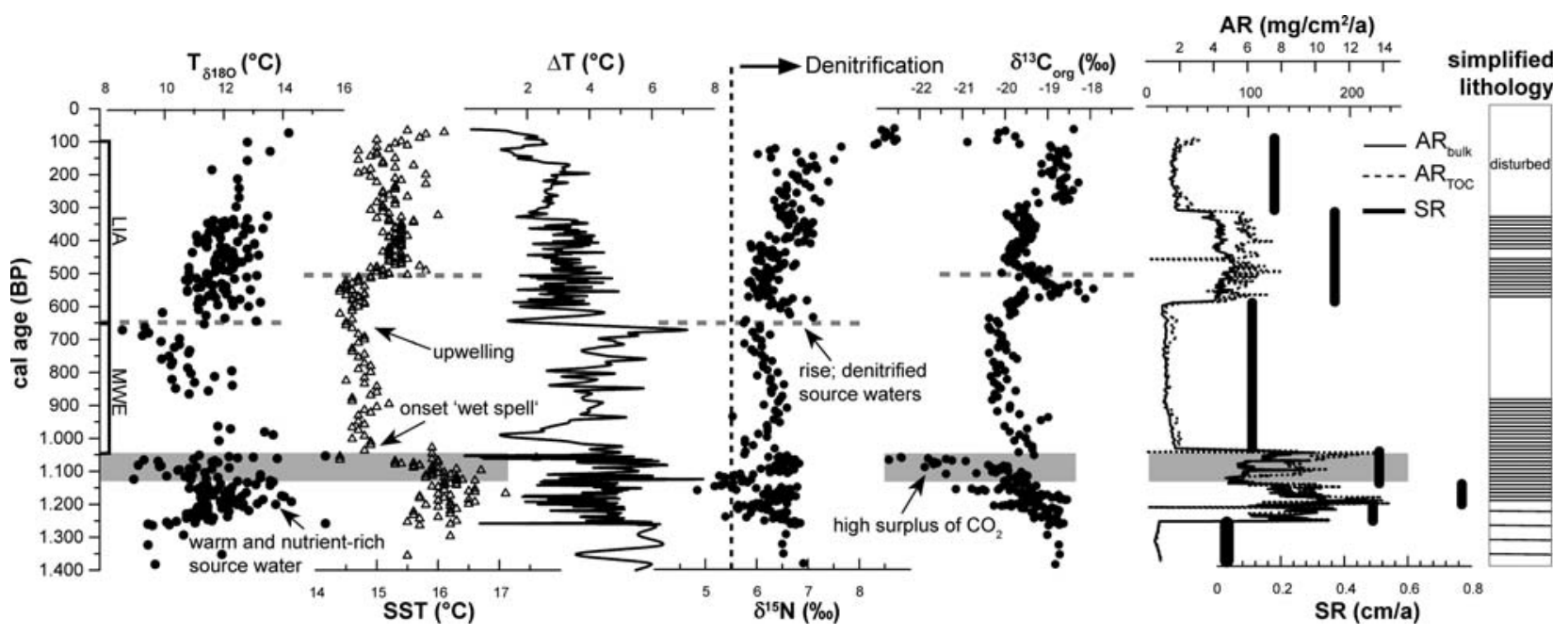

Figure 4. Proxy indicators of NAM1 vs. calendar years (see Fig. 3), zoomed in on the last 1400 years for the sake of higher resolution. Note the parallel developing of the temperature and ARs.

notions concerning this water mass are addressed when it comes to external forcing and inter-hemispheric climate teleconnections.

Between 1050 and $900 \mathrm{BP}, T_{\delta 180}$-data are too scarce to be reasonably interpreted (Fig. 4). The image gets clearer after $900 \mathrm{BP}$; then $T_{\delta 180}$ starts a steep decline and apparently imprints itself back on SST. Low primary production might again be due to reduced inflow of warm and nutrient-rich source water. Apart from that, high OM-decomposition (as inferred from the absence of laminae) may have contributed to the low ARs.

The dotted line at $650 \mathrm{BP}$ marks a pronounced jump in $T_{\delta 180}$ (Fig. 4). At the same time SSTs remain more or less constant. Enhanced wind-induced mixing immediately comes to mind, although this scenario provides no adequate explanation for the contemporaneous increase in $\delta^{15} \mathrm{~N}$. The simultaneous jump in $T_{\delta 180}$ and $\delta^{15} \mathrm{~N}$ is hardly coincident and suggests the introduction of warmer and more denitrified source waters. Their high nutrient content manifests itself in rising productivity, i.e. ARs; the small temporal offset is attributed to the "later" position of the age control point. The fact that SSTs remain constant while source waters are getting warmer testifies to a contemporaneous intensification of upwelling, which further contributes to the sound nutrient supply.

The nutrient surplus seems to outweigh the denitrification-induced shift towards higher $\delta^{15} \mathrm{~N}$-values, forcing $\delta^{15} \mathrm{~N}$ to slightly decline again. The $\delta^{13} \mathrm{C}_{\text {org }}$-values perform an opposite development and peak at $-18 \%$. Rising $\delta^{13} \mathrm{C}_{\text {org }}$ complies with the rising $\mathrm{CO}_{2}$-consumption as the biological production increases. The $\delta^{13} \mathrm{C}_{\mathrm{org}}{ }^{-}$ signals do not remain high for long, though. Their subsequent decline coincides with a rapid increase in SST by roughly $1^{\circ} \mathrm{C}$ at $500 \mathrm{BP}$ (Fig. 4; dotted line). In the meanwhile, $T_{\delta 180}$ remain more or less the same. The warming of the surface ocean suggests slackened upwelling and an increasing influence of insolation. The decline in $\delta^{13} \mathrm{C}_{\text {org }}$ may indicate less $\mathrm{CO}_{2}$-consumption and biological production. However, neither $\delta^{15} \mathrm{~N}$ nor the ARs show any corresponding reaction. Taken overall, the short-lived peak of $\delta^{13} C_{\text {org }}$ is not entirely conclusive.

During the past 100 years both $\delta^{18} \mathrm{O}_{\text {calcite }^{-}}$and UK'37-records denote rising temperatures. The $\delta^{15} \mathrm{~N}$ values exceed $8.5 \%$, the pool is highly denitrified. Concomitantly low $\delta^{13} \mathrm{C}_{\text {org }}$ suggests comparably low primary production rates, which might result from enhanced denitrification and corresponding nitrate deficits (Cline \& Kaplan 1975; Montoya 1994; Tyrrell \& Lucas 2002).

\section{The northern Benguela in the context of Holocene climate variability}

In this section we attempt to place our observations in the context of Holocene climate variability. In order to differentiate between local perturbations, regional- or global-scale events, we examine our findings alongside existing palaeo-climatic records.

\section{The global propagation of climate signals}

First of all, however, we shortly present the potential pathways of global climate signals and how they may impact on the northern Benguela system. In fact, the role of the ocean and atmosphere as transmission agents is highly debated (e.g. Vidal et al. 1999). It is pre-empted that climate signals seem to reach the northern Benguela both through the ocean, i.e. the thermohaline circulation system, and the atmosphere. For a better comprehension of the following please consult Figure 5 . 


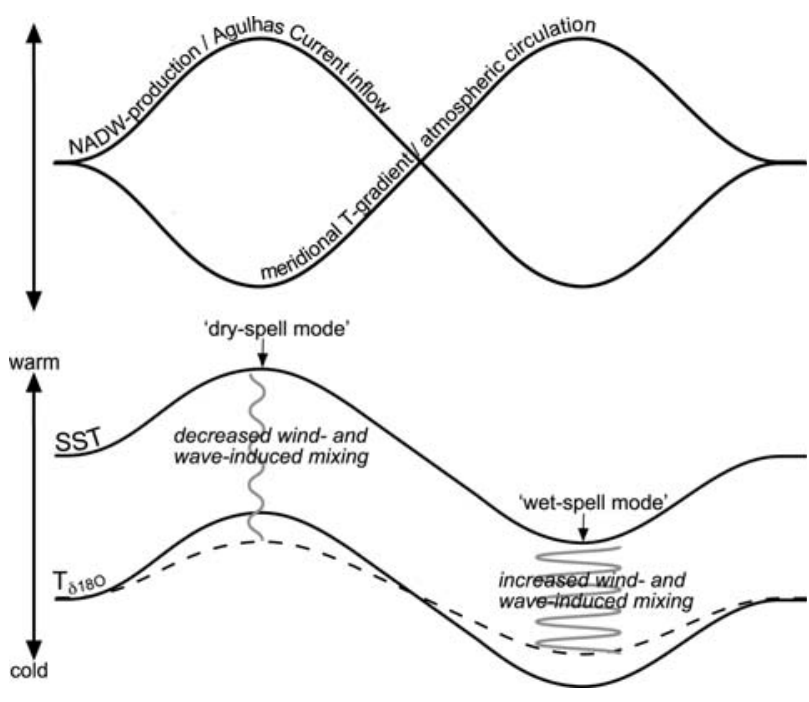

Figure 5. Simplified scheme showing the connection between atmospheric and oceanic forcing (above) and possible implications for surface (SST) and subsurface temperatures $\left(T_{\delta 180}\right)$ in the Benguela region (below). High NADW-production rates bring about warmer conditions in high northern latitudes (e.g. Bianchi \& McCave 1999). The meridional temperature gradient consequently declines and atmospheric circulation weakens; upwelling slackens and SSTs rise. The simultaneous increase in $T_{\delta 180}$ is due to the enhanced inflow of warm Agulhas Water as the ocean conveyor accelerates. The opposite holds true during times of reduced NADW-production. Note, however, that windand wave-induced mixing may attenuate the development of $T_{\delta 180}$ (dashed line).

\section{Pathway ocean}

Countless studies provide convincing evidence of a link between the intensity of thermohaline circulation and Holocene climate variability (e.g. Bianchi \& McCave 1999 and references therein; Marshall et al. 2001). As regards the Benguela region, the role of the ocean in the transfer of climate signals is controversially discussed. To our knowledge, there are two contrasting theories circulating on that issue:

Gordon (1986) suggests a link between North Atlantic Deep Water (NADW) production and the amount of warm, intermediate Indian Ocean Water introduced into the Benguela region. The stronger or weaker the global thermohaline overturn, the stronger or weaker the Agulhas Current gets and with it the heat transfer around the southern Cape (Fig. 1). Following this assumption, the cooling of the southern Benguela during the Younger Dryas and oxygen isotope stages 2-4 has been ascribed to slackened thermohaline overturn and a correspondingly reduced input of warm Agulhas Water (Cohen et al. 1992; Summerhayes et al. 1995).

Only strong Agulhas-signals are expected to weather the $1500 \mathrm{~km}$ long equatorward journey to the northern Benguela without being wiped out on the way. In order to assess the influence of thermohaline circulation on the temperature of central Namibian source waters (recorded by $T_{\delta 180}$ ), we compare fluctuations in NADW- production (Bianchi \& McCave 1999), with the $T_{\delta 180^{-}}$ record. As shown below, there are indeed a number of $T_{\delta 18 \mathrm{O}}$-fluctuations that are significantly correlated with NADW-production.

Contrary to our findings, sedimentary records from the continental slope off Namibia register temperature trends opposite to the ones in high northern latitudes. Kim et al. (2002) and Vidal et al. (1999) report rising temperatures during 'Heinrich Event 1', a period when the North Atlantic experienced prominent cooling ( $15000 \mathrm{BP})$. This inter-hemispheric asynchrony is attributed to decreased (or increased) heat transport from the South into the North Atlantic when the conveyor slows down (or accelerates) (Stuiver et al. 1995; Rühlemann et al. 1999; Kim et al. 2002). The anti-phase developing of isotope records from both polar ice sheets is the most prominent supporting evidence for the inter-hemispheric "seesaw" pattern (Blunier et al. 1998). Our data bear hardly any witness to such asynchrony. It seems like varying fractions of Agulhas Water in ESACW are the single most important factor on the shelf. It could be argued that beyond the shelf, its influence is overcompensated by cross-equatorial heat transfer.

\section{Pathway atmosphere}

At present the southern hemisphere, in comparison to the northern, is much cooler and its temperature gradient between high and low latitudes much bigger. This is predominantly due to the fact that the Antarctic continent is much colder than the Arctic Ocean. Owing to the steeper temperature gradient, atmospheric circulation is more vigorous in the southern hemisphere (Nicholson \& Flohn 1980).

When the high northern latitudes cool (as a result of decreased NADW-production for instance), the thermal contrast between both hemispheres is minimised. This results in an equatorward displacement of the ITCZ (Nicholson \& Flohn 1980), which further increases the southern hemisphere's temperature gradient (Tyson 1999) leading to an acceleration of the South Atlantic anticyclone in tandem with a strengthening of the eastern trade wind system (Rühlemann et al. 1999; Berger \& Wefer 2002). Enhanced zonal circulation brings about upwelling-related cooling in eastern boundary current regions (e.g. Hsieh \& Boer 1992; Kim et al. 2002). Indeed, northern Benguela SSTs were lower during glacial than interglacial stages (Kirst et al. 1999). SST-records from the eastern Walvis Ridge and the upper continental slope off Walvis Bay also support the notion that upwelling was generally more intense during glacials (Oberhänsli 1991; Summerhayes et al. 1995).

Cohen \& Tyson (1995) propose a valuable model, which predicts the response of coastal SSTs around South Africa to the displacement and intensification of the atmospheric circulation features associated with extended, i.e. decadal- to centennial-scale, wet and dry 
periods over the South African subcontinent (see also Cockcroft et al. 1987; Tyson 1999). Rainfall is generally derived from moisture transport in the tropical easterlies. The stronger the winds, the wetter the subcontinent becomes (Tyson \& Lindesay 1992). In more detail, over the continental interior - referred to as the 'summer rainfall region' - rainfall increases. Over the 'winter rainfall region', the southwestern part of South Africa, average rainfall declines instead. Still, the net result is an increase in precipitation receipts.

Note that the Namib Desert, notwithstanding lying in the summer rainfall region (Brook et al. 1999), does not necessarily receive more rainfall at times that the easterlies strengthen. This is because invigorated upwelling and the resultant cooling of coastal SSTs have a countervailing effect on the moisture availability along the west coast. Cold SSTs lower the evaporation and stabilise offshore high-pressure centres, which hamper moist marine air from entering the adjacent land (Berger \& Wefer 2002). As a consequence, imprints of climatic fluctuations in Namib-based records might often be rather ambiguous and less clear than in the betterwatered parts of the summer rainfall zone to the east.

Taken together, SST and continental rainfall records are potentially able to provide significant information about surface wind conditions and large-scale atmospheric circulation pattern. The conceptual model by Cohen \& Tyson (1995) posits that anomalously cool SST are likely to have been associated with invigorated tropical easterlies, increased rainfall in the summer rainfall region, drier conditions in the winter rainfall region as well as distinct droughts in the Namib Desert (hereafter referred to as the 'wet-spell mode'). Overall, the precipitation receipts of South Africa increase and average continental temperatures rise (note the opposite trend of SST and terrestrial temperatures). In contrast, increasing SSTs, decreasing mean continental temperatures, reversed precipitation pattern including slightly more rainfall over the Namib are associated with the 'dry-spell mode' when winds and upwelling slacken.

For the sake of completeness, it must be mentioned that terrestrial and marine temperature trends do not necessarily take opposite directions. The model represents a generalisation but does not preclude 'wet-spell modes' to be associated with continental cooling and 'dry-spell modes' to bring about higher terrestrial temperatures (Holmgren et al. 2003).

In order to evaluate the regional significance of northern Benguela SST-changes, we compare our data against records from the adjacent mainland and ocean areas.

Given the potential control of NADW-production on atmospheric forcing (Fig. 5) we also cross-check the northern Benguela SST-record against fluctuations in the conveyor speed. In this regard, we need to add that Figure 5 shows only part of the truth. In reality, the ocean-atmosphere feedback mechanism are much more complex than illustrated. As a matter of fact, the ocean does not only control the atmosphere, it is also the other way round. Unlike the atmosphere, however, the ocean is a fairly inert system. The oceanic transport of climate perturbations not only takes longer, the ocean integrates the high-frequency atmospheric forcing acting on it (Marshall et al. 2001). So despite the control of NADW-production on atmospheric forcing it is inadequate, therefore, to expect a one-to-one correspondence between NADW-production and the Benguela SST-record. Obvious connections between the conveyor speed and global temperature gradient are anticipated to predominantly appear in the form of major and longterm trends.

\section{Regional- and global-scale events}

With the knowledge about how global climate signals may reach the Benguela Upwelling we now compare the core records with already existing palaeo-archives, zooming in on fluctuations in our data that may be linked to larger-scale climatic events.

\section{Multi-decadal to centennial variability}

The immediate vicinity of the coast seems not be the only reason for the high SSTs around $5500 \mathrm{BP}$ (Fig. 3B). In fact, the Holocene Hypsithermal is centred around that time. Records from the South African subcontinent indicate an average temperature increase of $2{ }^{\circ} \mathrm{C}$ (Cohen \& Tyson 1995). Concomitantly rising surface ocean temperatures have already been reported by Cohen \& Tyson (1995), Shi et al. (2000) and Kim et al. (2002). Warmer SSTs suggest a weakening of upwelling-favourable winds, which agrees with the dramatic reduction of Namib dust transported into the Benguela and the reduction of rainfall over the South African interior (Cockroft et al. 1987; Cohen \& Tyson 1995 and references therein; Brook et al. 1999). In addition to this, higher SSTs are in accordance with wetter conditions in the coastal area as inferred from pollen records (Shi et al. 2000).

The drop of $T_{\delta 180}$ at $4200 \mathrm{BP}$ is markedly equivalent in timing to a slowdown of NADW-production (Fig. 6B) supporting the idea of reduced inflow of warm Agulhas Water as the conveyor decelerates. Apparently, the impulse of conveyor slowdown or acceleration propagates so fast as to provoke a more or less "immediate" interhemispheric response. Similarly, the slight increase in $T_{\delta 180}$ at $3200 \mathrm{BP}$ might be linked to the short-term acceleration of NADW-formation (Figs 6B-C) and enhanced Agulhas heat input.

The lacking response of $T_{\delta 180}$ to the subsequent slowdown in ocean conveyor speed (Fig. 6C) might be due to strengthened winds and enhanced vertical mixing; the presumed capacity of atmospheric forcing to attenuate or even outweigh the remote influence of the global ocean conveyor is illustrated in Figure 5. In fact, falling SSTs suggest an intensification of upwellingfavourable winds and fit the invigorated atmospheric 
circulation and rising meridional temperature gradient associated with the global glacier expansion, occurring in many parts of the world around that time (Cohen \& Tyson 1995 and references therein); more about the 'mid Holocene cooling' in the following section when it comes to millennial-scale trends.
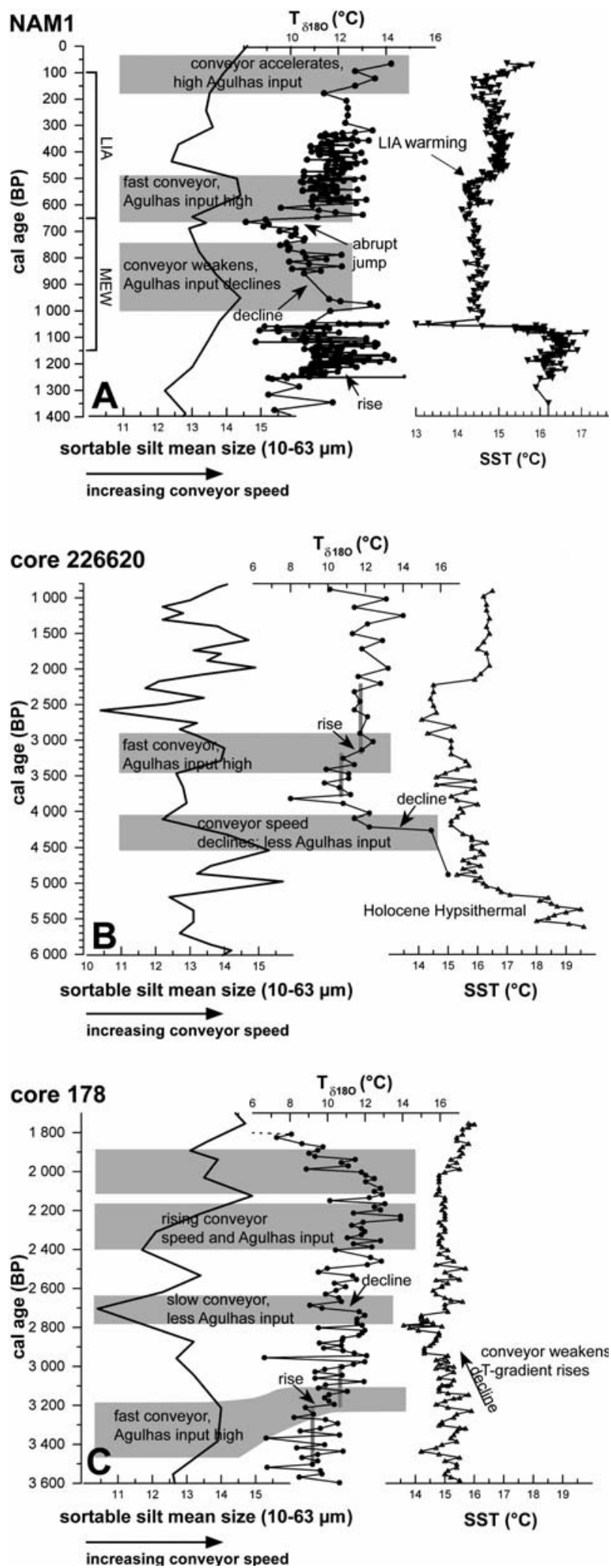

The fact that all three cores register an increase in $\Delta T$ around 2700 BP (Fig. 3) marks a significant change in the hydrology of the shelf environment. The comparison with NADW-production reveals that the findings are not necessarily purely local in character (shift of the cyclonic wind stress) as outlined before. In fact, the slight decline in $T_{\delta 180}$ at $2700 \mathrm{BP}$ coincides with minimum NADW-production (Fig. 6C) and may result, therefore, from a diminished fraction of warm Agulhas Water in ESACW. The conveyor slowdown at that time is also emphasised by Oppo et al. (2003). The subsequent trend towards higher $T_{\delta 180}$ (shortly interrupted at $2400 / 2500 \mathrm{BP}$ ) might in turn be related to the increasing speed of the global ocean conveyor and a greater fraction of Agulhas Water (Fig. 6C).

Around $2000 \mathrm{BP}$, terrestrial and marine records display striking parallels. Oxygen isotope data $\left(\delta^{18} \mathrm{O}\right)$ of stalagmites from the Cango Cave (transition between summer and winter rainfall region) and the Cold Air Cave (summer rainfall region) in southern and northeastern South Africa (Talma \& Vogel 1992; Holmgren et al. 2003), $\delta^{18} \mathrm{O}$-signals of mollusc shells in the southern Benguela region (Cohen et al. 1992) and SST-records of core 226620 and core 178 (Figs 3B-C) all testify to a pronounced event of warming around $2000 \mathrm{BP}$. This marked concurrence of marine and terrestrial records can hardly be coincident. It appears as if major climatic changes affect the South African region at that time. Interestingly, the warming coincides with the Roman Warm Period, a comparatively short spell of higher temperatures in Europe (Bianchi \& McCave 1999). Rising SST might indicate a stronger response to insolation as the global temperature gradient declines and the winds attenuate. Considering our above reasoning, the coincidence of larger-scale forcing and local perturbation (southward shift of upwelling) cannot be ruled out; again, more in the following section when it comes to millennial trends.

The sharp decline in $T_{\delta 180}$ after $2000 \mathrm{BP}$ (Fig. 6C) raises intriguing questions. Although NADW-production declines somewhat between 2100 and $1900 \mathrm{BP}$, the cooling is certainly too pronounced to be solely attribu-

Figure 6. NADW-production rates along with temperature records from NAM1 (A), core 226620 (B) and core 178 (C). Flow speed fluctuations are inferred from sediment grain-size data from the Iceland Basin (redrawn after Bianchi \& McCave 1999). Bigger grain-size implies faster deep-water masses and increased poleward flux of warm Atlantic waters. Variations in the conveyor speed are believed to influence the introduction of warm Agulhas Water, resulting in a synchronous temperature evolution of the Nordic Seas and the central Namibian source waters (recorded by $T_{\delta 180}$ ). SST is partly tied to the developing of $T_{\delta 180}$. Apart from that, SST directly reacts to changes in the atmospheric circulation, which is, in turn, linked to changes in NADW-formation (Fig. 5). Grey bars highlight potential links. MWE - Medieval Warm Epoch; approx. 1050-650 BP. LIA - Little Ice Age; approx. 650-100 BP (Tyson \& Lindesay 1992). 
ted to less Agulhas Water. Previous studies already reported colder subsurface temperatures off Walvis Bay, thus offering some support for our data (Tyson \& Lindesay 1992 and references therein). According to our above reasoning the extent of the cooling may result from the allochthonous nature of the $T_{\delta 180^{-} \text {-signals. }}$ However, a satisfying explanation is admittedly lacking and without additional data the mechanisms remain unclear.

Valuable compilations of terrestrial records covering the last two millennia of South African climate including the Medieval Warm Epoch (MWE) and the Little Ice Age (LIA) are found in Tyson \& Lindesay (1992) and Holmgren et al. (1999) (note that there are no universally accepted definitions as regards the duration and timing of the LIA and the MWE. Here, we stick to the dates proposed by Tyson \& Lindesay (1992)).

The Medieval Warm Epoch (approx. 1050 to 650 BP) is characterised by approximately four centuries of variable but generally warmer conditions. It is proposed that the state of the atmosphere is analogous to the state associated with the wet-spell mode (Cohen \& Tyson 1995; Tyson 1999). Corroborating evidence from stalagmite-based terrestrial rainfall records is given by Holmgren et al. (1999, 2003). The development of a forest along the Hoanib River in the northern Namib Desert (Vogel \& Rust 1990; Tyson \& Lindesay 1992) further testifies to increased rainfall receipts in the summer rainfall region. The parallel strengthening of the coastal high-pressure centre is apparently outweighed by the greater moisture availability in the river catchment to the east.

Our data substantiate the wet-mode functioning around that time. The abrupt decline in SST by nearly $2{ }^{\circ} \mathrm{C}$ at the onset of the MWE (Fig. 4) corroborates the invigoration of upwelling-favourable winds as proposed by the conceptual model outlined above. Its low chronological resolution notwithstanding, SST-data from GeoB1023-5 offshore Cape Frio in the north (Kim et al. 2002) record a simultaneous drop in temperature at the beginning of the last millennium. Mayewski et al. (2004) refer to the onset of the MWE as a short-lived RCC (rapid climate change) -event that coincides with the drought-related fall of the Maya civilization and the collapse of Greenland's colonies as the polar region cooled. The influence of varying NADW-production is again well worth considering. Figure 6A highlights the parallel decline in NADW-production and $T_{\delta 180}$ from 900 to $650 \mathrm{BP}$, a concurrency that seems too obvious to be ignored.

The Little Ice Age (approx. 650 to $100 \mathrm{BP}$ ) is the most extensive cool period since the Younger Dryas (Tyson \& Lindesay 1992). Despite being a phenomenon experienced in many parts of the world, it is not a centennial-long period of continuous cold. The LIA is characterised by considerable variability and instability, including substantial fluctuations in the atmospheric circulation strength. Distinct LIA-signals are not necessarily found and its local expression varies with region.
As regards the southern African continental interior, the Tyson model (Tyson 1986, 1999) posits a cool and dry LIA, accompanied by weakened tropical easterlies and slackened upwelling along the southwest African coast (Cohen \& Tyson 1995). Several terrestrial datasets assembled by Tyson \& Lindesay (1992) as well as a highresolution stalagmite record from the Cold Air Cave in NE-South Africa (summer rainfall region) confirm these model results (Holmgren et al. 1999, 2003).

Other studies draw reverse conclusions instead. Geomorphological, palynological and micromammalian evidence (summarized in Cohen \& Tyson 1995) indicate trends towards wetter conditions in the continental interior including intensified eastern trades and coastal upwelling. Corresponding SST-cooling has been found in sediments collected off Walvis Bay (Herbert 1987; Johnson 1988; both from Tyson \& Lindesay 1992), in the southern Benguela (Cohen et al. 1992) and on the Agulhas Bank (Cohen \& Tyson 1995).

As regards the early stage of the LIA (650 to $500 \mathrm{BP}$ ), our data support the scenario of intensified upwelling, thus corroborating the wet-mode functioning around that time (Fig. 4). The transition from the MEW to the LIA is considered the globally most distributed RCC of the late Holocene with pronounced and rapid changes in global-scale atmospheric circulation pattern (Mayewski et al. 2004; Maasch et al. 2005). A LIA-bound strengthening of the atmospheric circulation and resulting intensification of coastal upwelling has also been observed in other parts of the world (Cohen \& Tyson 1995).

Also note the contemporaneous increase in NADWformation and $T_{\delta 180}$ at $650 \mathrm{BP}$, i.e. the onset of the LIA (Fig. 6A), again confirming the influence of the thermohaline overturn on the temperature of the source water.

The marked increase in SST at 500 BP (Fig. 4) coincides with period of sudden warming ubiquitously interrupting the LIA in southern Africa (see Tyson \& Lindesay 1992 and references therein). Following our above reasoning the pronounced rise results from a short-term weakening of upwelling-favourable winds. By inference, the continental interior should have been drier at these times. However, conclusions reached by terrestrialbased records are contradictory (Cockkroft et al. 1987; Tyson \& Lindesay 1992; Cohen \& Tyson 1995; Holmgren et al. 1999). Disparities may be due to differences in the nature and timing of climatic events as well as the varying susceptibility of different environments to climatic fluctuations. Differences in the records' continuity, the large variety of methods applied (Heine 2005) and vast room for interpretation pose further discrepancies. In addition to this, imprecision due to dating is particularly problematic when it comes to comparatively short spells, such as the LIA. More high-resolution data are needed in order to resolve these ambiguities.

The post-LIA SST-rise may be in part linked to the $\mathrm{T}_{\delta 18 \mathrm{O}}$-increase. The warming of the source water might 
again result from rising NADW-formation or, more precisely, elevated Agulhas heat transfer (Fig. 6A). The SST-rise is corroborated by records from several adjacent multicores (MUC) originating from 22 to $24^{\circ} \mathrm{S}$ (Emeis et al. 2009). Slightly further south, towards the Lüderitz Upwelling, SSTs decline instead. It shows that spatial SST-variations on the Namibian shelf were markedly heterogeneous during the last couple of centuries. When it comes to the most recent past, i.e. AD 1850 to present, inhomogeneities in SST further increase (Emeis et al. 2009). The findings are ascribed to local perturbations, such as changes in the wind stress curl and accompanied shifts in the position of upwelling. Unfortunately, age determinations of the available MUCs are insufficient to enable any deeper comparison with NAM1.

Irrespective of the sense and magnitude of SSTchanges, all MUCs registered increasing $\delta^{15} \mathrm{~N}$-signals in the youngest sediments. This corresponds with our record (Fig. 4) and implies a higher degree of denitrification in the source waters.

\section{The thermohaline overturn and the availability of nutrients}

The direct correlation between the temperature records and $\mathrm{AR}_{\mathrm{TOC}}$ in NAM 1 (Fig. 4) has already been an issue (see above). Apparently, warmer source waters tend to contain higher amounts of nutrients. Taking this observation to its logical conclusion, it follows that NADW-formation not only affects temperature but also controls the amount of nutrients and primary production rates. On closer examination, core 178 lends support to this hypothesis. The rise in $T_{\delta 180}$ at $3200 \mathrm{BP}$ and from $2400 \mathrm{BP}$ on is accompanied by rising $\mathrm{AR}_{\mathrm{TOC}}$ and NADW-formation. On the other hand, the sudden cooling at $2700 \mathrm{BP}$ is paralleled by collapsing ARs and minimum NADW-formation (Figs 3C, 6C).

The direct relationship between NADW-production and nutrient content has already previously been observed. Hay \& Brock (1992) suggest that northern Benguela source waters were less nutrient-rich during stadials, i.e. at times when NADW-production slowed down considerably. Data from the continental slope off southwest Africa further confirms the diminished nutrient supply during stadials (Berger \& Wefer 2002).

The question is, what are the reasons for the decline in both nutrients and temperature as the conveyor decelerates? Much of the nutrients are brought in by the poleward transport of nutrient-rich SACW from the Angola Dome region. ESACW from the Agulhas Retroflection area in the south is the second water mass of interest. If NADW-formation slackens, the conveyor decelerates as a whole. A weakening of all associated currents may induce decreased heat input via the Agulhas Retroflection and reduced nutrient supply from the Angola Dome region (see also Berger \& Wefer 2002). Although being merely speculative at the present stage, this scenario offers a reasonable explanation for the si- multaneous decrease of temperature and primary production (Fig. 4).

Despite diminished nutrient supply, productivity proxies all along the SW-African coast testify to enhanced primary production during glacial times. It is suggested that strongly intensified winds and upwelling compensated for the nutrient deficiency in the upwelled waters (Berger \& Wefer 2002). This does not apply to the middle and late Holocene when upwelling rarely makes up for the lack of nutrients in the source water. On most occasions it appears as though the availability of nutrients would be primarily controlled by the type of source water rather than by the intensity of upwelling. Still, this certainly not excludes fluctuations in upwelling to either improve or deteriorate the nutrient situation. For instance, slackened upwelling at $2700 \mathrm{BP}$ (as inferred from rising SST; Fig. 3C) probably further aggravated the nutrient deficiency, while enhanced upwelling after $2400 \mathrm{BP}$ and at $600 \mathrm{BP}$ (as inferred from constant SST at rising $T_{\delta 180}$; Figs $\left.3 \mathrm{C}, 4\right)$ may have contributed to a sound nutrient supply.

\section{Millennial-scale variability}

When it comes to millennial scales, orbital forcing is often considered one of the major causes of Holocene climate variance (Tyson 1999; Lorenz et al. 2006). Over the course of the middle and late Holocene, changes in precession and obliquity induce the continuous displacement of the perihelion towards austral summer. The resultant shift in the seasonal cycle of solar irradiance causes the thermal equator to strengthen (Tyson 1999; Lorenz et al. 2006) and the high northern latitudes to cool (Kim \& Schneider 2004). As a consequence, the ITCZ moves southward (Nicholson \& Flohn 1980; Tyson 1999) and the trade wind system intensifies. Sediments from the upper continental slope off Walvis Bay (Summerhayes et al. 1995) as well as different sites on the South African continent testify to the southward movement of the ITCZ over the last millennia (Tyson 1999; Scott \& Woodborne 2007 and references therein). The decline in SST between 5000 and $2200 \mathrm{BP}$ recorded by core 226620 (Fig. 6B) fits the invigoration of the eastern trades also reasonably well.

However, according to Lorenz et al. (2006) orbitallydriven insolation changes exert only a minor influence in the SE-Atlantic realm. They report discrepancies between model simulations and reconstructed SSTs off Namibia concluding that millennial-scale SST-shifts tend to be dominated by processes related to thermohaline and atmospheric forcing.

In fact, an apparent dependence of millennial-scale SST-variance on NADW-production changes can be inferred from Figure 7A. The parallel evolution of SST and NADW-production fits the theory outlined in Figure 5, substantiating the influence of the thermohaline overturn on atmospheric circulation and the atmospherecontrolled teleconnection between both hemispheres. The decline in SST between 5000 and $2200 \mathrm{BP}$ is re- 
ferred to as the mid Holocene cooling (Holmgren et al. 2003) and accords with the steepened meridional temperature gradient and strengthening of upwelling-favourable winds as the conveyor decelerates. Further evidence of cooling in the Benguela has been found in GeoB1023-5 retrieved offshore Cape Frio (Kim et al. 2002), as well as in mollusc shells from the Agulhas Bank (Cohen \& Tyson 1995) and the southern Benguela region (Cohen et al. 1992). By inference, the continental interior should have been wetter at these times but terrestrial rainfall records are again highly contradictory (Brook et al. 1999; Tyson 1999; Holmgren et al. 2003; Scott \& Woodborne 2007 and references therein).

The marked increase in SST at 2200 BP coincides with the Roman Warm Period and is markedly equivalent in timing with a reversal of the conveyor speed (Fig. 7A). As NADW-production reaccelerates and the high latitudes warm, both winds and upwelling slacken and SST rises (Fig. 5). Admittedly, if the smoothing curves in Figure 7A were lacking, there would be no immediate visual agreement between both data sets. The observation deserves a mention nonetheless but needs to be verified by additional data.

The concurrences shown in Figure 7B are much clearer. The temperatures in the northern Benguela Upwelling and the Cold Air Cave located in NE-South Africa (Holmgren et al. 2003) follow markedly similar millennial trends. According to Holmgren et al. (2003) the millennial- and centennial-scale variability in the $T_{\delta 180}$-data is due to atmospheric circulation changes associated with displacements of southern hemisphere circulation features. In fact, the large distance between both sites suggests perturbations operating on a large spatial scale.

The comparison of SST-trends in the coastal upwelling regions off NW- and SW-Africa (Fig. 8) bears further evidence of large-scale atmospheric forcing. Both GeoB 2007-2 (Kim et al. 2007) and NAM1 exhibit markedly similar SST-variability during the total of the last 1500 years. Here also, the synchrony appears too pronounced to be coincident although the ultimate causes of the parallels are still to be established.

It appears that external climate forcing leaves its marks on a large spectrum of time scales. Contrary to centennial-scale variability, however, we found no correlation between NADW-formation and the quality of the source water (in terms of $T_{\delta 180}$ or nutrient content) when it comes to millennial scales. On millennial scales we only found some correlation between NADW-production and SST-records (Fig. 7A) and it seems as though climate signals reaching the northern Benguela nonetheless being triggered by changes in NADW-production - are rather transferred by the atmosphere than the ocean. This, however, is still to be substantiated by other data.

The common idea of orbital forcing being the ultimate trigger behind millennial-scale climate variance does not entirely fit the circumstances; although applicable to the decline in SST between 5000 and 2200 BP
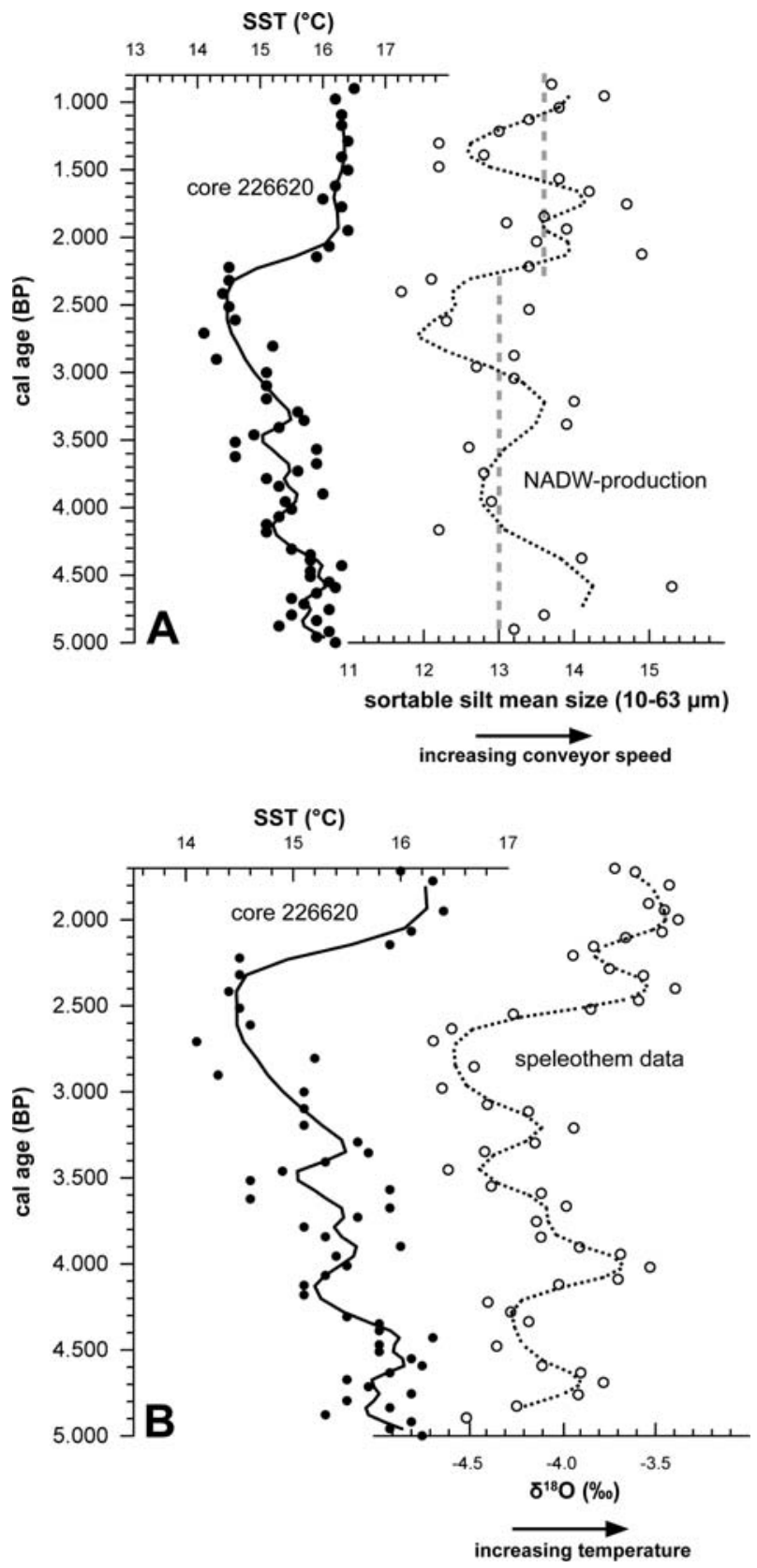

Figure 7. A. Millennial-scale SST-evolution recorded by core 226620 alongside NADW-production (redrawn after Bianchi \& McCave 1999), both smoothed with a 3 point running mean. The dashed lines show average grain sizes before and after the 2200 BP-event (Roman Warm Period). The millennial view reveals the possibility of upwelling being indirectly controlled by NADW-production. This observation fits the theory illustrated in Figure 5 implying that atmospheric forcing, being triggered by changes in NADW-production, may be capable of producing responses in the Benguela Upwelling; B. Millennial-scale SST-evolution (core 226620) alongside high-resolution speleothem $\delta^{18} \mathrm{O}$ records from the Cold Air Cave in NE-South Africa ( 3 point running mean; redrawn after Holmgren et al. 2003). Note the markedly similar evolution of the marine and terrestrial records.

(see above), it fails to explain the pronounced warming at 2200 BP. Our findings agree with Lorenz et al. (2006) who suggest the overriding influence of oceanic and atmospheric forcing in the SE-Atlantic realm. 


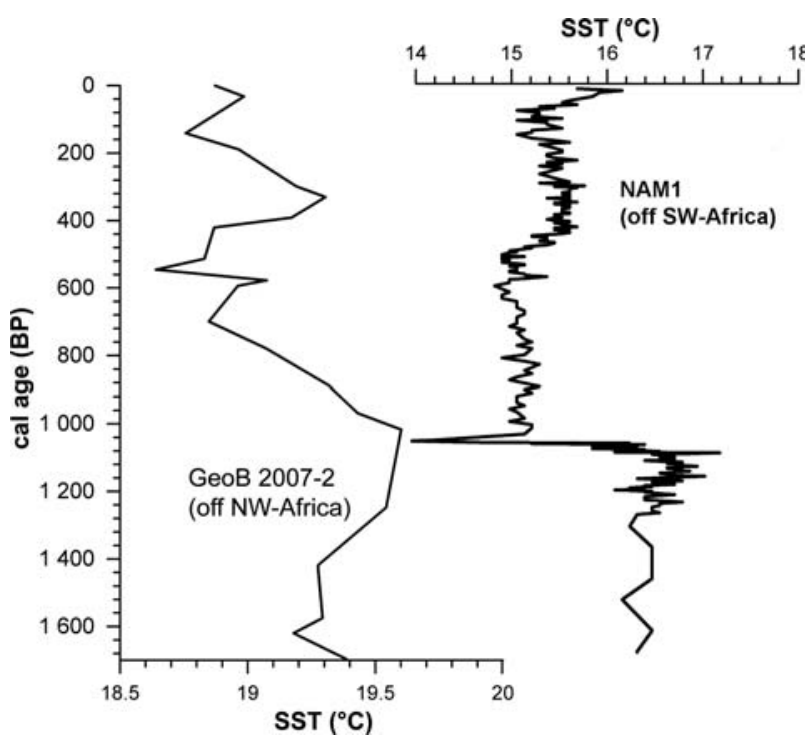

Figure 8. Comparison of the SST-evolution in the northern Benguela (NAM1) and off NW-Africa (GeoB 2007-2; redrawn after Kim et al. 2007). Both coastal upwelling areas exhibit strikingly contemporaneous reversals and trends in SST during the last one and a half millennia. This includes the slight warming around $1200 \mathrm{BP}$ and the subsequent cooling associated with the MWE. The warming around $500 \mathrm{BP}$ is also markedly synchronous.

\section{Outlook and future scenarios}

Eastern boundary upwelling regions strongly affect the global carbon cycle and heat balance of the planet and their role in the global climate system should not be underestimated. As regards the Benguela Current and the associated upwelling, the heat transfer into the North Atlantic is of special interest, with the equatorward heat transport being globally unique (Berger et al. 1989; Berger \& Wefer 2002). Not only plays the Benguela an active role in the global climate system, but it is also considered extremely vulnerable to climate change (Shannon \& O'Toole 2003). Potential implications are still highly speculative though.

Recent monitoring programs have shown that North Atlantic SSTs have increased in the course of the last decades (Marshall et al. 2001 and references therein; Schubert et al. 2006). Still, in the long run and with continued climate warming, most projections anticipate severe and rapid cooling in the high northern latitudes. Although such changes do not seem to be imminent, worst-case scenarios even expect a total cessation of deep-water formation (Schubert et al. 2006). Whether the larger global temperature gradient and intensified upwelling would then compensate for the nutrient deficiency in the source water as it happened in glacial times (Berger \& Wefer 2002) remains to be seen.

\section{Conclusions}

[1] The three cores document climate variability in the northern Benguela Upwelling back to $5500 \mathrm{BP}$. The re- solution of the data ranges from multi-decadal (NAM1) over centennial (core 178) to millennial scale (core 226620). The selection of proxy indicators provides a valuable basis for robust palaeo-climatic and -environmental reconstructions of the region. The proxies often correlate well with one another, which substantiates the credibility of the data also where fluctuations are only subtle.

Usually, studies are based on one palaeo-thermometer only. The combined analysis of SST and $\mathrm{T}_{\delta 180}$ proved a useful tool in order to differentiate between climate signals transferred by the ocean or the atmosphere. Our results provide convincing evidence that properties and functioning of the northern Benguela system are intimately linked, on a large spectrum of time scales, to changes in both atmospheric circulation features and the thermohaline overturn.

[2] The $\delta^{15} \mathrm{~N}$-records indicate that denitrification seems to have prevailed since the modern shelf circulation system has established. Average SST-records agree with today's temperature distribution suggesting that the location of upwelling did not substantially change through time.

Although the median values of the proxy indicators lie within today's range, the northern Benguela experienced pronounced and rapid perturbations during the middle and late Holocene, and apparently, not all are purely local in character. We have thoroughly compared our data with other palaeo-environmental records. Unfortunately a meaningful comparison with archives from the adjacent mainland is often hampered due to the insufficiently fine resolution and poor age determinations of terrestrial geoarchives. Besides, continental temperature and rainfall records are not unambiguous (Cohen \& Tyson 1995; Heine 2005). Moreover it is often difficult to clearly differentiate between local-, regionaland global-scale events.

Despite all this, the northern Benguela exhibits some strong correlations with both temperature and rainfall records from various sites across the South African subcontinent. Significant parallels with data from high northern latitudes provide evidence for inter-hemispheric climatic teleconnections. We were rather surprised at the frequent evidence of links between the core records and global climate variability (Holocene Hypsithermal, Roman Warm Period, LIA, etc.). Given the extremely heterogeneous and dynamic nature of the Benguela Upwelling, we anticipated global climate signals to be largely obliterated. Irrespective of whether or not some of the observed concurrences are pure coincidence, it definitively seems like the Holocene global climate history did not go by the northern Benguela without trace.

[3] One of the key findings is that the source waters are liable to substantial changes in the nutrient content and temperature. Available information supports the hypothesis that these changes are, at least partly, caused by varying rates of NADW-production. During periods of slackened NADW-formation, $T_{\delta 180}$ declines and pri- 
mary production diminishes. The latter is taken as an indication of decreased nutrient supply, the former agrees with reduced introduction of warm Agulhas Water as the global conveyor decelerates. With increased NADWformation the conditions reverse.

On the basis of the available evidence, we incline to the view that fluctuations in primary production reflect the dynamics of currents and source water masses rather than the dynamics of the atmosphere and upwelling. This is exactly opposite to glacial times when atmospheric forcing outweighed the nutrient deficiency of the source waters (Berger \& Wefer 2002).

Although definite conclusions are conditional upon further investigation, our findings substantiate the previously observed control of Agulhas Water on the quality of ESACW (e.g. Gordon 1986). Apparently, its influence reaches higher up north than hitherto discovered (NB: The variability of inter-ocean exchange in the Agulhas Retroflection area is currently being investigated by a project called ASTTEX, Agulhas-South Atlantic Thermohaline Transport Experiment (Project homepage: http://gyre.umeoce.maine.edu/ASTTEX/). The project is conducted against the background that inter-ocean communication plays an important role in global climate change.).

[4] Predictions about the future stability of the global ocean conveyor vary substantially and region-specific consequences of abrupt changes in NADW-production are also highly speculative. As regards the Benguela system, a severe slowdown of the ocean conveyor may have adverse effects on primary production and the ecosystem as a whole due to deteriorating amounts of nutrients in the source waters. If, however, the system switches back to the glacial mode, increased upwelling may be able to compensate for that nutrient deficiency.

There is no single dominant factor controlling variability in the northern Benguela system. Apart from local perturbations, the influence of both atmospheric and oceanic forcing seems beyond all question. Still, the full array of feedback mechanisms, ocean-atmosphere interactions and causal links including the implications for the Benguela upwelling are not entirely understood yet.

All remaining uncertainites notwithstanding, our data yield novel information on how external forcing acted on the northern Benguela Upwelling in the past. The study and thorough comparison of three highly resolved cores from the northern Benguela shelf is hitherto unique. When worked into numerical and conceptual models the data will contribute to the refinement of future climate predictions for the South African realm and the development of a long-term sustainable fisheries management plan.

\section{Acknowledgements}

The authors thank Ewgenija Kuhl, Nina Holzner and Michelle Mohr for sample preparation and taking measurements. We are furthermore indebted to the reviewers for their useful comments and suggestions as well as to Cameron Paul for proof-reading. The research was funded by the German Research Foundation (DFG) in the frame of the project STR356/3.

\section{References}

Altabet, M. A. \& Francois, R. 1994. The use of nitrogen isotopic ratio for reconstruction of past changes in surface ocean nutrient utilization. In Zahn, R., Pedersen, T. F., Kaminski, M. A. \& Labeyrie L. (eds). Carbon Cycling in the Glacial Ocean: Constraints on the Ocean's Role in Global Change. NATO ASI Series, Vol. 17. Springer-Verlag, Heidelberg: pp. 281-306.

Bakun, A. \& Weeks, S. J. 2004. Greenhouse gas buildup, sardines, submarine eruptions and the possibility of abrupt degradation of intense marine upwelling ecosystems. - Ecology Letters 7: 10151023 .

Bemis, B. E., Spero, H. J., Bijma, J. \& Lea, D. W. 1998. Reevaluation of the oxygen isotopic composition of planktonic foraminifera: experimental results and revised paleotemperature equations. Paleoceanography 13: 150-160.

Berger, W. H., Smetacek, V. S. \& Wefer, G. 1989. Productivity of the ocean: present and past. John Wiley and Sons, Chichester.

Berger, W. H. \& Wefer, G. 2002. On the reconstruction of upwelling history: Namibia upwelling in context. - Marine Geology 180: $3-28$.

Bianchi, G. G. \& McCave, N. 1999. Holocene periodicity in North Atlantic climate and deep-ocean flow south of Iceland. - Nature 397: 515-517.

Blanz, T., Emeis, K.-C. \& Siegel, H. 2005. Controls on alkenone unsaturation ratios along the salinity gradient between the open ocean and the Baltic Sea. - Geochimica et Cosmochimica Acta 69 (14): 3589-3600.

Blunier, T., Chappellaz, J., Schwander, J., Dällenbach, A., Stauffer, B., Stocker, T. F., Raynaud, D., Jouzel, J., Clausen, H. B., Hammer, C. U. \& Johnsen, S. J. 1998. Asynchrony of Antarctic and Greenland climate change during the last glacial period. - Nature 394: 739-743.

Boebel, O., Lutjeharms, J., Schmid, C., Zenk, W., Rossby, T. \& Barron, C. 2003. The Cape Cauldron: a regime of turbulent interocean exchange. - Deep-Sea Research II 50: 57-86.

Bremner, J. M. \& Willis, J. P. 1993. Mineralogy and geochemistry of the clay fraction of sediments from the Namibian continental margin and the adjacent hinterland. - Marine Geology 115: 85-116.

Brook, A. B., Marais, E. \& Cowart, J. B. 1999. Evidence of wetter and drier conditions in Namibia from tufas and submerged speleothems. - Cimbebasia 15: 29-39.

Brüchert, V., Altenbach, A. V., Bening, G., Bockelmann, F., Currie, B., Donath, J., Dübecke, J., Endler, R., Erdmann, S., Ertan, T., Fuchs, B., Klockgether, G., Krüger, S., Kuypers, M. M. M., Lass, H. U., Lavik, G., Lilienthal, S., Leipe, T., Nickel, G., Noli-Peard, K., Ohde, T., Schulz, B., Schulz, H., Siegel, H., Struck, U., Wulf, J., Zitzmann, S. \& Zonneveld, K. 2004. The Benguela Upwelling System 2003, Part 3, Cruise No. 57, Leg 3, March 15 - April 13, 2003, Walvis Bay, Namibia - Dakar. - Meteor Berichte 4: 1-53.

Bubnov, V. A. 1972. Structure and characteristics of the oxygen minimum layer in the southeast Atlantic Ocean. - Oceanology 12: 193-201.

Chapman, P. \& Shannon, L. 1985. The Benguela ecosystem Part II. Chemistry and related processes. - Oceanography and Marine Biology Annual Review 23: 183-251.

Chapman, P. \& Shannon, L. 1987. Seasonality in the oxygen minimum layers at the extremities of the Benguela system. - South African Journal of Marine Science 5: 51-62.

Christiansen, C. C. \& Kunzendorf, H. 1998. Datings and sedimentation rate estimations during GOBEX. A summary. - Meereswissenschaftliche Berichte 34: 55-76. 
Cline, J. D. \& Kaplan, I. R. 1975. Isotopic fractionation of dissolved nitrate during denitrification in the eastern tropical North Pacific Ocean. - Marine Chemistry 3: 271-299.

Cochrane, K. L., Augustyn, C. J., Bianchi, G., De Barros, P., Fairweather, T., Iitembu, J., Japp, D., Kanandjembo, A., Kilongo, K., Moroff, N., Nel, D., Roux, J.-P., Shannon, L. J., Van Zyl, B. \& Vaz Velho, F. 2007. Results and conclusions of the project "Ecosystem approaches for fisheries management in the Benguela Current Large Marine Ecosystem”. - FAO Fisheries Circular 1026: 166.

Cockcroft, M. J., Wilkinson, M. J. \& Tyson, P. D. 1987. The application of a present-day climate model to the late quaternary in southern Africa. - Climate Change 10: 161-181.

Cohen, A. L., Parkington, J. E., Brundrit, G. B. \& van der Merwe, N. J. 1992. A Holocene Marine Climate Record in Mollusc Shells from the Southwest African Coast. - Quaternary Research 38: 379-385.

Cohen, A. L. \& Tyson, P. D. 1995. Sea-surface temperature fluctuations during the Holocene off the south coast of Africa: implications for terrestrial climate and rainfall. - The Holocene 5 (3): 304-312.

Copenhagen, W. J. 1953. The periodic mortality of fish in the Walvis region - a phenomenon within the Benguela Current. - Investigational Report Division of Fisheries-Union of South Africa 14: $1-35$.

Diester-Haass, L., Heine, K., Rothe, P. \& Schrader, H. 1988. Late Quaternary history of continental climate and the Benguela Current off South West Africa. - Palaeogeography, Palaeoclimatology, Palaeoecology 65: 81-91.

Emeis, K.-C., Brüchert, V., Currie, B., Endler, R., Ferdelman, T., Kiessling, A., Leipe, T., Noli-Peard, K., Struck, U. \& Vogt, T. 2004. Shallow gas in shelf sediments of the Namibian coastal upwelling ecosystem. - Continental Shelf Research 24 (6): 627642 .

Emeis, K.-C., Struck, U., Leipe, T. \& Ferdelman, T. G. 2009. Variability in upwelling intensity and nutrient regime in the coastal upwelling system offshore Namibia: results from sediment archives. - International Journal of Earth Sciences 98: 309-326.

Erez, J. \& Luz, B. 1983. Experimental paleotemperature equation for planktonic foraminifera. - Geochimica et Cosmochimica Acta 47: 1025-1031.

Fairbanks, R. G. 1989. A 17,000-year glacio-eustatic sea level record: influence of glacial melting rates on the Younger Dryas event and deep-ocean circulation. - Nature 342: 637-642.

Francois, R., Altabet, M. A. \& Burckle, L. H. 1992. Glacial to interglacial changes in surface nitrate utilization in the Indian sector of the southern ocean as recorded by sediment $\delta^{15} \mathrm{~N}$. - Paleoceanography 7: 589-606.

Fry, B. $1996 .{ }^{13} \mathrm{C} /{ }^{12} \mathrm{C}$ fractionation by marine diatoms. - Marine Ecology Progress Series 134: 283-294.

Gaye-Haake, B., Lahajnar, N., Emeis, K.-C., Unger, D., Rixen, T., Suthhof, A., Ramaswamy, V., Schulz, H., Paropkari, A. L., Guptha, M. V. S. \& Ittekkot, V. 2005. Stable nitrogen isotopic ratios of sinking particles and sediments from the northern Indian Ocean. - Marine Chemistry 96: 243-255.

Gordon, A. L. 1986. Interocean Exchange of Thermocline Water. Journal of Geophysical Research 91 (C4): 5037-5046.

Hart, T. J. \& Currie, R. I. 1960. The Benguela Current. - Discovery Report 31: 123-127.

Hay, W. W. \& Brook, J. C. 1992. Temporal variation in intensity of upwelling off Southwest Africa. In Summerhayes, C. P., Prell, W. L. \& Emeis K.-C. (eds). Upwelling Systems: Evolution since the Early Miocene. - Geological Society Special Publication 64: $463-497$.

Heine, K. 2005. Holocene climate of Namibia: a review based on geoarchives. - African Study Monographs Supplement 30: 119133.
Hemleben, C. \& Bijma, J. 1994. Foraminiferal population dynamics and stable carbon isotopes. In Zahn, R., Pedersen, T. F., Kaminski, M. A. \& Labeyrie L. (eds). Carbon Cycling in the Glacial Ocean: Constraints on the Oceańs Role in Global Change. NATO ASI Series, Vol. 17. Springer-Verlag, Heidelberg: pp. 145-166.

Hollander, D. J. \& McKenzie, J. A. 1991. $\mathrm{CO}_{2}$ control on carbon-isotope fractionation during aqueous photosynthesis: A paleo- $p \mathrm{CO}_{2}$ barometer. - Geology 19 (9): 929-932.

Holmes, M. E., Müller, P. J., Schneider, R. R., Segl, M., Pätzold, J. \& Wefer, G. 1996. Stable nitrogen isotopes in Angola Basin surface sediments. - Marine Geology 134: 1-12.

Holmes, M. E., Müller, P. J., Schneider, R. R., Segl, M. \& Wefer, G. 1998. Spatial variations in euphotic zone nitrate utilization based on $\delta^{15} \mathrm{~N}$ in surface sediments. - Geo-Marine Letters 18 (1): $58-$ 65.

Holmes, B., Eichner, C., Struck, U. \& Wefer, G. 1999. Reconstructions of surface ocean nitrate utilization using stable nitrogen isotopes in sinking particles and sediments. In Fischer, G. \& Wefer, G. (eds). Use of Proxies in Paleoceanography: Examples from the South Atlantic. Springer-Verlag, Heidelberg: pp. 447-468.

Holmes, E., Lavik, G., Fischer, G., Segl, M., Ruhland, G. \& Wefer, G. 2002. Seasonal variability of $\delta^{15} \mathrm{~N}$ in sinking particles in the Benguela upwelling region. - Deep-Sea Research I 49: 377-394.

Holmgren, K., Karlén, W., Lauritzen, S. E., Lee-Thorp, J. A., Partridge, T. C., Piketh, S., Repinski, P., Stevenson, C., Svanered, O. \& Tyson, P. D. 1999. A 3000-year high-resolution stalagmitebased record of palaeoclimate for northeastern South Africa. - The Holocene 9 (3): 295-309.

Holmgren, K., Lee-Thorp, J. A., Cooper, G. R. J., Lundblad, K., Partridge, T. C., Scott, L., Sithaldeen, R., Talma, A. S. \& Tyson, P. D. 2003. Persistent millennial-scale climatic variability over the past 25,000 years in Southern Africa. - Quaternary Science Research 22: $2311-2326$.

Hsieh, W. W. \& Boer, G. J. 1992. Global climate change and ocean upwelling. - Fisheries Oceanography 1: 333-338.

Kim, J.-H., Schneider, R. R., Müller, P. J. \& Wefer, G. 2002. Interhemispheric comparison of deglacial sea-surface temperature patterns in Atlantic eastern boundary currents. - Earth and Planetary Science Letters 1994: 383-393.

Kim, J.-H. \& Schneider, R. R. 2004. GHOST global database for alkenone-derived 6ka sea-surface temperatures. http://www.pangaea.de/ Projects/GHOST/.

Kim, J.-H., Meggers, H., Rimbu, N., Lohmann, G., Freudenthal, T., Müller, P. J., \& Schneider, R. R. 2007. Impacts of the North Atlantic gyre circulation on Holocene climate off northwest Africa. Geology 35 (5): 387-390.

Kirst, G. J., Schneider, R. R., Müller, P. J., Storch, I. von \& Wefer, G. 1999. Late Quaternary Temperature Variability in the Benguela Current System Derived from Alkenones. - Quaternary Research 52: $92-103$.

Knowles, R. 1982. Denitrification. - Microbiological Reviews 46 (1): 43-70.

Kreutz, K. J., Mayewski, P. A., Meeker, L. D., Twickler, M. S., Whitlow, S. I. \& Pittalwala, I. I. 1997. Bipolar Changes in Atmospheric Circulation During the Little Ice Age. - Science 277: 12941296.

Kristen, I. 2003. Paläoklimatologische Untersuchungen im Auftriebsgebiet vor Namibia. Unpublished MSc-Thesis, Department für Geo- und Umweltwissenschaften, Ludwig Maximilians Universität, München.

Kuypers, M. M. M., Lavik, G., Woebken, D., Schmid, M., Fuchs, B. M., Amann, R., Jørgensen, B. B. \& Jetten, M. S. M. 2005. Massive nitrogen loss from the Benguela upwelling system through anaerobic ammonium oxidation. - Proccedings of the National Academy of Science 102 (18): 6478-6483.

Lavik, G., Stührmann, T., Brüchert, V., van der Plas, A., Mohrholz, V., Lam, P., Mußmann, M., Fuchs, B. M., Amann, R., Lass, U. \& 
Kuypers, M. M. M. 2009. Detoxification of sulphidic African shelf waters by blooming chemolithotrophs. - Nature 459: 581-585.

Libes, S. M. \& Deuser, W. G. 1988. The isotope geochemistry of particulate nitrogen in the Peru Upwelling Area and the Gulf of Maine. - Deep-Sea Research I 35 (4): 517-533.

Lorenz, S. J., Kim, J.-H., Rimbu, N., Schneider, R. R. \& Lohmann, G. 2006. Orbitally driven insolation forcing on Holocene climate trends: Evidence from alkenone data and climate modeling. - Paleoceanography 21: 1-14.

Lutjeharms, J. R. E. \& Meeuwis, J. M. 1987. The extent and variability of southeast Atlantic upwelling. - South African Journal of Marine Science 5: 85-94.

Lutjeharms, J. R. E. \& Stockton, P. L. 1987. Kinematics of the upwelling front off southern Africa. - South African Journal of Marine Science 5: 35-49.

Maasch, K. A., Mayewski, P. A., Rohling, E. J., Stager, J. C., Karlén, W., Meeker, L. D. \& Meyerson, E. A. 2005. A 2000-year context for modern climate change. - Geografiska Annaler A (1): 7-15.

Marshall, J., Kushnir, Y., Battisti, D., Chang, P., Czaja, A., Dickson, R., Hurrell, J., McCartney, M., Saravanan, R. \& Visbeck, M. 2001. North Atlantic climate variability: phenomena, impacts and mechanisms. - International Journal of Climatology 21: 1863-1898.

Mayewski, P. A., Rohling, E. E., Stager, J. C., Karlén, W., Maasch, K. A., Meeker, L. D., Meyerson, E. A., Gasse, F., van Kreveld, S., Holmgren, K., Lee-Thorph, J., Rosqvist, G., Rack, F., Staubwasser, M., Schneider, R. R. \& Steig, E. J. 2004. Holocene climate variability. - Quaternary Research 62: 243-255.

Meisel, S. \& Struck, U. 2011. The potential distortion of sedimentary $\delta^{15} \mathrm{~N}$ and $\mathrm{C}_{\text {org }} / \mathrm{N}$ ratios by $\mathrm{NH}_{4}{ }^{+}$and the effects of pre-analysis sample treatment. - Fossil Record 14 (2): 141-152.

Meisel, S., Struck, U. \& Emeis, K.-C. 2011. Nutrient dynamics and oceanographic features in the central Namibian upwelling region as reflected in $\delta^{15} \mathrm{~N}$-signals of suspended matter and surface sediments. - Fossil Record 14 (2): 153-169.

Mohrholz, V., Bartholomae, C. H., van der Plas, A. K. \& Lass, H. U. 2008. The seasonal variability of the northern Benguela undercurrent and its relation to the oxygen budget on the shelf. - Continental Shelf Research 28 (3): 424-441.

Montoya, J. P. 1994. Nitrogen isotope fractionation in the modern ocean: Implications for the sedimentary record. In Zahn, R., Pedersen, T. F., Kaminski, M. A. \& Labeyrie, L. (eds). Carbon Cycling in the Glacial Ocean: Constraints on the Oceańs Role in Global Change. NATO ASI Series, Vol. 17. Springer-Verlag, Heidelberg: pp. 259-279.

Montoya, J. P. \& McCarthy, J. J. 1995. Isotopic fractionation during nitrate uptake by phytoplankton growth in continuous culture. Journal of Plankton Research 17: 439-464.

Moroshkin, K. V., Bubnov, V. A. \& Bulatov, R. P. 1970. Water circulation in the eastern South Atlantic Ocean. - Oceanology 10 (1): 27-34.

Mulitza, S., Arz, H., Kemle-von Mücke, S., Moos, C., Niebler, H.-S., Pätzold, J. \& Segl, M. 1999. The South Atlantic carbon isotope record of planktic foraminifera. In Fischer, G. \& Wefer, G. (eds). Use of Proxies in Paleoceanography: Examples from the South Atlantic. Springer-Verlag, Heidelberg: pp. 427-445.

Murray, J. W. 1991. Ecology and distribution of planktonic foraminifera. In Lee, J. J. \& Anderson O. R. (eds). Biology of Foraminifera. Academic Press, Burlington/Massachusetts: pp. 255-284.

Nelson, G. \& Hutchings, L. 1983. The Benguela upwelling area. Progress in Oceanography 12: 333-356.

Nicholson, S. E. \& Flohn, H. 1980. African environmental and climatic changes and the general atmospheric circulation in late Pleistocene and Holocene. - Climatic Change 2: 313-348.

Niebler, H.-S., Huberten, H.-W. \& Gersonde R. 1999. Oxygen Isotope Values of Planktic Foraminifera: A Tool for the Reconstruction of Surface Water Stratification. In Fischer, G. \& Wefer, G. (eds). Use of Proxies in Paleoceanography: Examples from the South Atlantic. Springer-Verlag, Heidelberg: pp. 165-189.
Oberhänsli, H. 1991. Upwelling signals at the northeastern Walvis Ridge during the past 500,000 years. - Paleoceanography 6: 53-71.

Oppo, D. W., McManus, J. F. \& Cullen, J. L. 2003. Deepwater variability in the Holocene epoch. - Nature 422: 277-278.

Orbigny A. d' 1839. Voyage dans l'Amerique meridionale. - Foraminifers 5: 1-86.

Ostrom, N. E. \& Macko, S. A. 1991. Late Wisconsinan to present sedimentation of organic matter off northern Newfoundland in response to climatological events. - Continental Shelf Research 11: $1285-1296$.

Ostrom, N. E., Macko, S. A., Deibel, D. \& Thompson, R. J. 1997. Seasonal variation in the sTable carbon and nitrogen isotope biogeochemistry of a coastal cold ocean environment. - Geochimica et Cosmochimica Acta 61 (14): 2929-2942.

Packard, T. T., Garfield, P. C. \& Codispoti, L. A. 1983. Oxygen consumption and denitrification below the Peruvian upwelling. In Suess, E. \& Thiede, J. (eds). Coastal Upwelling: Its Sediment Record. Plenum Press, New York: pp. 147-173.

Rau, G. H. 1994. Variations in sedimentary $\delta^{13} \mathrm{C}$ as a proxy for past changes in ocean and atmospheric $\mathrm{CO}_{2}$ concentrations. In Zahn, R., Pedersen, T. F., Kaminski, M. A. \& Labeyrie, L. (eds). Carbon Cycling in the Glacial Ocean: Constraints on the Ocean's Role in Global Change. NATO ASI Series, Vol. 17. Springer-Verlag, Heidelberg: pp. 307-321.

Ravelo, A. C. \& Fairbanks, R. G. 1992. Oxygen Isotopic Composition of Multiple Species of Planktonic Foraminifera: Recorders of the Modern Photic Zone Temperature Gradient. - Paleoceanography 7 (6): $815-831$

Ren, H., Sigman, D. M., Meckler, A. N., Plessen, B., Robinson, R. S., Rosenthal, Y. \& Haug, G. H. 2009. Foraminiferal Isotope Evidence of Reduced Nitrogen Fixation in the Ice Age Atlantic Ocean. Science 323: 244-248.

Rühlemann, C., Mulitza, S., Müller, P. J., Wefer, G. \& Zahn, R. 1999. Warming of the tropical Atlantic Ocean and slowdown of thermohaline circulation during the last deglaciation. - Nature 402: 511-514.

Sachs, J. P. \& Repeta, D. J. 1999. Oligotrophy and nitrogen fixation during eastern Mediterranean sapropel events. - Science 286: $2485-2488$.

Schelske, C. L. \& Hodell, D. A. 1991. Recent changes in productivity and climate of Lake Ontario detected by isotopic analysis of sediments. - Limnology and Oceanography 36: 961-975.

Schubert, R., Schellnhuber, H.-J., Buchmann, N., Epiney, A., Grießhammer, R., Kulessa, M., Messner, D., Rahmstorf, S. \& Schmid, J. 2006. The Future Oceans - Warming Up, Rising High, Turning Sour, Special Report. German Advisory Council on Global Change (WBGU), Berlin.

Scott, L. \& Woodborne, S. 2007. Vegetation history inferred from pollen in Late Quaternary faecal deposits (hyraceum) in the Cape winter-rain region and its bearing on past climates in South Africa. - Quaternary Science Reviews 26: 941-953.

Shannon, L. V. 1985. The Benguela ecosystem. Part I. Evolution of the Benguela, physical features and processes. - Oceanography and Marine Biology Annual Review 23: 105-182.

Shannon, L. V., Boyd, A. J., Brundrit, G. B. \& Taunton-Clark, J. 1986. On the existence of an El Niño-type phenomenon in the Benguela system. - Journal of Marine Research 44 (3): 495-520.

Shannon, L. V. \& Pillar, S. C. 1986. The Benguela Ecosystem. Part III: Plankton. - Oceanography and Marine Biology Annual Review 24: $65-170$.

Shannon, L. V. \& Nelson, G. 1996. The Benguela: Large Scale Features and Processes and System Variability. In Wefer, G., Berger, W. H. \& Siedler, D. (eds). The South Atlantic: Present and Past Circulation. Springer-Verlag, Heidelberg: pp. 163-210.

Shannon, L. V. \& O'Toole, M. J. 2003. Sustainability of the Benguela ex Africa semper aliquid novi. In Hempel, G. \& Sherman, K. (eds). Large marine ecosystems of the world: trends in exploitation, protection and research. Elsevier B. V., Amsterdam: pp. 227-253. 
Shi, N., Dupont, L. M., Beug, H.-J. \& Schneider, R. 2000. Correlation between Vegetation in Southwestern Africa and Oceanic Upwelling in the Past 21,000 Years. - Quaternary Research 54: 72-80.

Sigman, D. M., Altabet, M. A., Michener, R., McCorkle, D. C., Fry, B. \& Holmes, R. M. 1997. Natural abundance-level measurement of the nitrogen isotopic composition of oceanic nitrate: an adaption of the ammonia diffusion method. - Marine Chemistry 57 (3-4): 227-242.

Sigman, D. M., Altabet, M. A., McCorkle, D. C., Francois, R. \& Fischer, G. 2000. The $\delta^{15} \mathrm{~N}$ of nitrate in the Southern Ocean: nitrogen cycling and circulation in the ocean interior. - Journal of Geophysical Research 105 (C8): 599-614.

Spero, H. J. \& DeNiro, M. J. 1987. The influence of symbionts photosynthesis on the $\delta^{18} \mathrm{O}$ and $\delta^{13} \mathrm{C}$ values of planktonic foraminiferal shell calcite. - Symbiosis 4: 213-228.

Stander, G. H. 1964. The Benguela Current off South West Africa. Investigational Report of the Marine Research Laboratory of South West Africa 12: 1-43.

Stramma, L. \& Peterson, R. G. 1989. Geostrophic Transport in the Benguela Current region. - Journal of Physical Oceanography 19: 1440-1448.

Struck, U., Emeis, K.-C., Alheit, J., Schneider, R., Eichner, C. \& Altenbach, A.-V. 2002. Changes of the upwelling rates of nitrate preserved in the $\delta^{15} \mathrm{~N}$-signature of sediments and fish scales from the diatomaceous mud belt off Namibia. - GeoBios 35: 3-11.

Stuiver, M. \& Braziunas, T. F. 1993. Modeling atmospheric ${ }^{14} \mathrm{C}$ influences and ${ }^{14} \mathrm{C}$ ages of marine samples to 10,000 BC. - Radiocarbon 35 (1): 137-189.

Stuiver, M., Grootes, P. M. \& Braziunas, T. F. 1995. The GISP2 $\delta^{18} \mathrm{O}$ Climate Record of the Past 16,500 Years and the Role of the Sun, Ocean, and Volcanoes. - Quaternary Research 44: 341-354.

Stuiver, M., Reimer, P. J. \& Reimer, R. W. 2005. CALIB 5.0. [WWW program and documentation].

Summerhayes, C. P., Kroon, D., Rosell-Mele, A., Jordan, R. W., Schrader, H.-J., Hearn, R., Villanueva, J., Grimalt, J. O. \& Eglington, G. 1995. Variability in the Benguela Current upwelling system over the past 70,000 years. - Progress in Oceanography 35: 207-251.

Talma, S. A. \& Vogel, J. C. 1992. Late Quaternary Paleotemperatures Derived from a Speleothem from Cango Caves, Cape Province, South Africa. - Quaternary Research 37: 203-213.

Tedesco, K., Thunell, R., Astor, Y. \& Muller-Karger, F. 2007. The oxygen isotope composition of planktonic foraminifera from the
Cariaco Basin, Venezuela: Seasonal and interannual variations. Marine Micropaleontology 62: 180-193.

Tyrrell, T. \& Lucas, M. I. 2002. Geochemical evidence of denitrification in the Benguela upwelling system. - Continental Shelf Research 22: 2497-2511.

Tyson, P. D. 1986. Climatic Change and Variability in Southern Africa. Oxford University Press, Cape Town.

Tyson, P. D. 1999. Atmospheric circulation changes and palaeoclimates of southern Africa. - South African Journal of Science 95: 194-201.

Tyson, P. D. \& Lindesay, J. A. 1992. The climate of the last 2000 years in southern Africa. - The Holocene 2 (3): 271-278.

van Zyl, B. J. 2010. A Decade of Namibian Fisheries and Biodiversity Management. www.unep.org/bpsp/Fisheries/Fisheries $\% 20 \mathrm{Case} \% 20$ Studies/VANZYL.pdf, access date April 2010.

Vidal, L., Schneider, R. R., Marchal, O., Bickert, T., Stocker, T. F. \& Wefer, G. 1999. Link between the North and South Atlantic during the Heinrich events of the last glacial period. - Climate Dynamics 15: 909-119.

Vogel, J. C. \& Rust, U. 1990. Ein in der Kleinen Eiszeit (Little Ice Age) begrabener Wald in der nördlichen Namib. - Berliner Geographische Studien 30: 15-34.

Vogt, T. 2002. Akustische Fazies auf dem Schelf und oberen Kontinentalrand vor Namibia - Auswertung von PARASOUND-Ergebnissen der Reise METEOR 48-2. M.Sc. Thesis, University of Greifswald, Greifswald.

Voss, M., Altabet, M. \& Bodungen, B. von. 1996. $\delta^{15} \mathrm{~N}$ in sedimenting particles as indicator for euphotic zone processes. - Deep-Sea Research I 43: 33-47.

Wada, E. \& Hattori, A. 1978. Nitrogen isotope effects in the assimilation of inorganic nitrogenous compounds by marine diatoms. Geomicrobiology Journal 1: 85-101.

Wada, E. 1980. Nitrogen isotope fractionation and its significance in biogeochemical processes occurring in marine environments. In Goldberg, E. D., Horibe, Y. \& Saruhashi, K. (eds). Isotope Marine. Uchida Rokakuho, Tokyo: pp. 375-398.

Waser, N. A. D., Turpin, D. H., Harrison, P. J., Nielsen, B. \& Calvert, S. E. 1998. Nitrogen isotope fractionation during uptake and assimilation of nitrate, nitrite, ammonium and urea by a marine diatom. - Limnology and Oceanography 43: 215-224.

Wefer, G. \& Berger, W. 1991. Isotope paleontology: growth and composition of extant calcareous species. - Marine Geology 100: 207-248. 